\title{
Draft genome sequence of Xanthomonas fragariae reveals reductive evolution and distinct virulence-related gene content
}

\author{
Joachim Vandroemme ${ }^{1,2}$, Bart Cottyn ${ }^{1}$, Steve Baeyen ${ }^{1}$, Paul De Vos ${ }^{2}$ and Martine Maes ${ }^{1 *}$
}

\begin{abstract}
Background: Xanthomonas fragariae (Xf) is a bacterial strawberry pathogen and an A2 quarantine organism on strawberry planting stock in the EU. It is taxonomically and metabolically distinct within the genus Xanthomonas, and known for its host specificity. As part of a broader pathogenicity study, the genome of a Belgian, virulent Xf strain (LMG 25863) was assembled to draft status and examined for its pathogenicity related gene content.

Results: The Xf draft genome (4.2 Mb) was considerably smaller than most known Xanthomonas genomes ( 5 Mb). Only half of the genes coding for TonB-dependent transporters and cell-wall degrading enzymes that are typically present in other Xanthomonas genomes, were found in Xf. Other missing genes/regions with a possible impact on its plant-host interaction were: i) the three loci for xylan degradation and metabolism, ii) a locus coding for a B-ketoadipate phenolics catabolism pathway, iii) XCS, one of two Type II Secretion System coding regions in Xanthomonas, and iv) the genes coding for the glyoxylate shunt pathway. Conversely, the Xf genome revealed a high content of externally derived DNA and several uncommon, possibly virulence-related features: a Type VI Secretion System, a second Type IV Secretion System and a distinct Type III Secretion System effector repertoire comprised of multiple rare effectors and several putative new ones.
\end{abstract}

Conclusions: The draft genome sequence of LMG 25863 confirms the distinct phylogenetic position of Xf within the genus Xanthomonas and reveals a patchwork of both lost and newly acquired genomic features. These features may help explain the specific, mostly endophytic association of Xf with the strawberry plant.

\section{Background}

Xanthomonas fragariae (Xf) is a bacterial strawberry pathogen and the cause of angular leaf spot. It was first described in the United States in 1962 [1] and has since spread globally. Under favourable conditions the pathogen may cause significant damage to both plant stock and strawberry production [2]. Xf is a quarantine pest on planting stock within the EU [3], which may explain why this generally considered mild pathogen has remained at the heart of scientific and legislative debate for decades. Xf is a distinct and homogeneous species within the otherwise complex and highly dynamic genus Xanthomonas [4-7]. A certain degree of infraspecific

\footnotetext{
* Correspondence: martine.maes@ilvo.vlaanderen.be

'Institute for Agricultural and Fisheries Research (ILVO), Plant Sciences Unit Crop Protection, Merelbeke, Belgium

Full list of author information is available at the end of the article
}

diversity within $\mathrm{Xf}$ has been observed, but in general it is considered as a coherent and stable species [8-10].

Unlike its clear taxonomic position, the disease-related capabilities of Xf are still obscure. One well-established characteristic of $\mathrm{Xf}$ is its narrow host range: Fragaria spp. are the only natural hosts, although close relatives of Fragaria, such as Potentilla fruticosa and P. glandulosa, showed symptoms after artificial inoculation and therefore are considered potential hosts [11]. Another, poorly characterized feature of $\mathrm{Xf}$ is its symptomless persistence in strawberry crops [12], which holds significant relevance for $\mathrm{Xf}$ as quarantine organism in strawberry planting stock. Molecular testing repeatedly demonstrated Xf presence in symptomless rhizomes of strawberry plants intended for planting $[13,14]$. Knowledge on the in planta movement of $\mathrm{Xf}$ is limited:so far, only one study presented experimental evidence for the endophytic
Ciomed Central

(c) 2013 Vandroemme et al.; licensee BioMed Central Ltd. This is an open access article distributed under the terms of the Creative Commons Attribution License (http://creativecommons.org/licenses/by/2.0), which permits unrestricted use, distribution, and reproduction in any medium, provided the original work is properly cited. 
spread of Xf down from infected strawberry leaves to the rhizome and to newly emerging runners and daughter plants [15]. Xf is a challenging organism to study because of its fastidious nature on most common growth media [1], and its rapidly declining viability after contact with strawberry leaf extracts [16]. Moreover, Xf appeared insusceptible to genetic manipulation, which hampered our efforts in developing fluorescent and functional mutants (unpublished results).

A whole genome sequence of $\mathrm{Xf}$ can provide insight in its life style and help solve some of the technical problems it presents in the laboratory. Recent advances in sequencing technology and bioinformatics, together with emerging commercial whole genome sequencing services, have resulted in rapid and cost-effective means of generating draft genomes fit for most plant-pathology related studies [17]. Also within Xanthomonas, multiple genome sequences are available and already provided interesting insights in the most common pathogenicity determinants of the genus $[18,19]$. One of the final technical challenges associated with next-generation sequencing techniques is the presence of repetitive genomic sequences [20]. Multiple paired-read datasets with varying insert sizes are often used to resolve assembly ambiguities associated with these repetitive sequences, or at least to bridge sequence gaps by concatenating related contigs into larger scaffolds. In addition, several software tools providing automatic scaffold gap-closure have recently been released: Gapcloser [21], IMAGE [22] and Gapfiller [23].

The aim of the current study was to generate a draft genome sequence of a Belgian, virulent Xf strain (LMG 25863) and to analyse its virulence-related gene content by comparison to available Xanthomonas whole-genome sequences. Two commercially obtained paired-read datasets were combined, and an automatic gap-closure algorithm was applied, to overcome encountered assembly problems related to repetitive DNA. Here, we present the resulting draft genome sequence of Xf LMG 25863 and the observed virulence-related features.

\section{Results and discussion}

\section{Repetitive DNA content complicates genome assembly}

Assembling the draft genome sequence of $\mathrm{Xf}$ was more challenging than anticipated. A first de novo assembly using a single Paired-End (PE) Illumina short-read dataset (Table 1) did not meet our expectations: although the contig number and N50-values of this initial draft genome sequence were on par with comparable assemblies of other Xanthomonas genomes (e.g. [24]), it was considerably smaller than anticipated (3,9 $\mathrm{Mb}$ instead of $5 \mathrm{Mb}$ ) and revealed an exceptionally high Insertion Sequences (IS) related repetitive DNA content. A second, Mate-Paired
(MP) Illumina short-read dataset with a larger insert size was generated to avoid incomplete genome assembly caused by read ambiguity. The MP dataset did not improve the de novo assembly (data not shown), and the initial PE-based de novo assembly was used to start a second assembly stage that included scaffolding of the de novo assembly with the MP dataset, and subsequent application of the automatic gap-closing algorithm Gapcloser [21]. There was a clear improvement in both assembly quality and read disambiguation, and the current draft sufficed for our plant pathology aimed research goals. Given the quick evolution of genome assembly algorithms, the public available raw sequence data generated in this study could result in a finished genome assembly in the near future.

In its current form, the draft genome of LMG 25863 consists of 96 contigs with a total contig size of 4.182.545 bp. The final draft genome of LMG 25863 was confirmed to contain an abundant IS-content. During RAST annotation, for example, 420 of the total 3786 recognized Coding DNA Sequences (CDS) in the draft genome were identified as IS-related and represented $5 \%$ of the total genome size. Of course, this number may be artificially inflated by partial and frame-shifted ORFs caused by incomplete assembly of the highly repetitive IS. However, the frequent association of the IS with sequence gaps, ambiguous read positions and orphan contigs in the draft genome all seem to confirm their abundance. Truncated CDS, due to incomplete assembly in the Xf draft genome or in the other 25 available Xanthomonas genomes (Table 2), were assumed as complete in our comparative analysis. The frequently encountered IS-families in Xf seemed common for Xanthomonas genomes (Figure 1), although during blast queries two types annotated in RAST as "IS1647" and "tis1421" appeared to be more related to Ralstonia and Burkholderia genomes.

\section{Phylogenetic affiliation of $X$. fragariae to other Xanthomonas species}

In this study, we compared the Xf draft genome with available whole genome sequences of 25 other Xanthomonas strains (Table 2). First, we determined the phylogenetic affiliation among these 26 genomes using the concatenated partial sequences of four housekeeping genes $\operatorname{gyr} B$, $a t p D$, dnaK, and $r p o D$ ) and the structural gene fyuA [40-42]. The results of the MLSA (Figure 2) were congruent with earlier phylogenetic studies of the genus Xanthomonas $[40,41]$. The subdivision between the "core" of the genus and the two outliers $X$. albilineans GPE PC73 and X. sacchari NCPPB 4393 was most evident. Also, Xf clearly represented a distinct phylogenetic lineage within the Xanthomonas core group. 
Table 1 Main characteristics of initial de novo and final draft genome assembly of $X$. fragariae LMG 25863

\begin{tabular}{rrr}
\hline & de novo assembly & Final draft genome sequence \\
\hline Contigs (> 200 bp) & 478 & 96 \\
Total Contig Size (bp) & 3.877 .791 & 61 \\
N50 contig number ${ }^{\mathbf{a}}$ & 21.221 & 4.182 .545 \\
$\mathbf{N} 50$ length (bp) & 10 \\
Average coverage & 158 & 131.420 \\
Mapped Reads (\% of total) & $12.846 .936(88.8 \%)$ & 159 \\
Reads in Aligned Pairs (\% of total) & $8.485 .028(58.7 \%)$ & $14.345 .704(99.2 \%)$ \\
\hline
\end{tabular}

${ }^{a}$ minimum set of contigs that represent at least $50 \%$ of total genome sequence. ${ }^{b}$ Size of the smallest contig in the N50 set.

\section{$X f$ reveals genome reduction similar to $X$. oryzae and $X$. albilineans}

Even after the second genome assembly, the total contig size of the Xf draft genome $(4.2 \mathrm{Mb})$ was still implying a considerable genome reduction. Because genome reduction had already been reported for $X$. albilineans (Xalb) and $X$. oryzae pv. oryzae (Xoo) [25], we compared the CDS content of Xf with that of Xalb GPE PC73 and Xoo KACC 10331 using the EDGAR software framework [43]. We further included $X$. campestris pv. campestris ATCC 33913 (Xcc) and X. euvesicatoria 85-10 (Xcv), respectively a vascular and a non-vascular pathogen, as references of non-reduced genomes. EDGAR analysis indicated a substantial genome reduction in $\mathrm{Xf}$, which was at least in part similar to Xoo and Xalb (Figure 3). This was most apparent from the 490 CDS shared by Xcc and Xcv but absent in Xalb, Xoo and Xf. Additionally, the 195 CDS exclusively missing in Xf suggested that the genome reduction in Xf was more extensive than in Xoo (84 exclusively missing CDS), but not as extreme as in Xalb (367 exclusively missing CDS). The lists of missing and present CDS, acquired from the EDGAR analysis (Additional file 1: Table S1), were used as a starting point for all further genome comparisons in this study, and were checked by independent protein and nucleotide blast queries in all 26 Xanthomonas genomes before inclusion in this manuscript.

\section{The reduced Xf genome has the major virulence-related gene regions}

The lists of CDS from the EDGAR analysis (Additional file 1: Table S1) indicated that Xf did not lose critical pathogenesis-related gene clusters reported for Xanthomonas. Contrary to the more reduced Xalb genome, for example, the Xf genome contained the hrp gene cluster coding for the structural elements of the Type III Secretion System (T3SS) and the gum gene cluster for extracellular polysaccharide (EPS) synthesis (Table 3). It also contained the gene cluster coding for a common Type IV Secretion System (T4SS) in Xanthomonas, which was entirely missing in Xoo and only partly retained in Xcv. Xf did lose the xcs-coded Type II Secretion System (T2SS), similar to Xoo and Xalb, but this gene cluster was reported as less critical for Xanthomonas pathogenicity than the clearly present xps-coded T2SS [44]. Also reported as unessential for virulence and absent in Xf, are the gum-associated genes gumN, gumO and gumP, and the $r p f$-associated genes $r p f D$ (truncated) and rpfI [45].

Other noteworthy gene regions that were indicated as absent in Xf by EDGAR analysis and confirmed by blast queries, were i) the glyoxylate shunt pathway coding locus $[46,47]$, which was also missing in Xoo and Xalb, ii) the three loci of the Carbohydrate Utilization (CUT) system involving TonB-dependent transporters for xylan degradation and metabolism in $X$. campestris $[48,49]$, iii) the genes coding for the $k d p$ potassium transport system [50] and, iv) a gene region coding for a ß-ketoadipate phenolics degradation pathway [51] that was also found partly absent in Xoo (Table 4).

Although some absent gene-regions in $\mathrm{Xf}$ may have virulence-related implications, the genome reduction in $\mathrm{Xf}$ seems to weaken nutritional and adaptive flexibility rather than clear virulence functions. For example, the absence of all three xylan degradation loci and the $ß$ ketoadipate pathway may indicate that Xf is unable to respectively degrade xylan and metabolize the phenolic components of lignin, two important elements of the secondary plant cell wall [49]. Perhaps, the opinion that primarily soil bacteria have been associated with lignin degradation [52], might suggest that the main role of the $ß$-ketoadipate pathway lays in saprophytic survival. Likewise, though the glyoxylate shunt pathway has been linked to successful symbiotic and pathogenic plantbacterial interactions, it does so by increasing metabolic fitness through growth on $\mathrm{C}_{2}$-compounds [46]. Potassium is another important nutritional element, crucial for cell turgor maintenance, activation of cellular enzymes and $\mathrm{pH}$ homeostasis. The $k d p$ potassium transport system is widely distributed among bacteria and serves as an emergency $\mathrm{K}^{+}$-scavenging system that is only expressed and activated under extreme environmental stress [50]. Maybe these missing functions are redundant for Xf's existence in the strawberry leaf apoplast. Among the 26 analysed Xanthomonas genomes, the xylan degradation 


\section{Table 2 Genomes used in this study}

\begin{tabular}{|c|c|c|c|c|c|}
\hline Strain & Host & Disease & Genome size (Mb) & Genbank record $^{\mathbf{b}}$ & Reference \\
\hline X. albilineans GPE PC73 & Sugarcane & Leaf Scald & 3.76 & [Genbank:NC_013722] & [25] \\
\hline X. arboricola LMG 19145 & Strawberry & Leaf Blight $^{a}$ & 4.86 & unreleased & Unpublished \\
\hline X. arboricola LMG 19146 & Strawberry & Leaf Blight ${ }^{a}$ & 5.09 & unreleased & Unpublished \\
\hline X. arboricola pv. pruni LMG 25862 & Apricot, Plum \& peach & Bacterial Spot & 5.02 & unreleased & Unpublished \\
\hline X. axonopodis (citri) pv. citri 306 & Citrus & Bacterial Canker A & 5.17 & [Genbank:NC_003919] & [26] \\
\hline X. axonopodis pv. citrumelonis F1 (FL 1195) & Citrumelo & Bacterial Spot & 4.97 & [Genbank:NC_016010] & [27] \\
\hline X. axonopodis pv. punicae LMG 859 & Pomegranate & Bacterial Blight & 4.94 & [Genbank:NZ_CAGJ01000000] & [28] \\
\hline X. campestris (vasicola) pv. musacearum NCPPB 4381 & Banana & Bacterial Wilt & 5.42 & [Genbank:NZ_ACHS01000000] & [29] \\
\hline X. campestris (vasicola) pv. vasculorum NCPPB 702 & Sugarcane & Gumming Disease & 4.78 & [Genbank:NZ_ACHT00000000] & [29] \\
\hline X. campestris pv. campestris ATCC 33913 & Crucifers & Black Rot & 5.08 & [Genbank:NC_003902] & [26] \\
\hline X. campestris pv. campestris 8004 & Crucifers & Black Rot & 5.15 & [Genbank:NC_007086] & [30] \\
\hline X. campestris pv. campestris B100 & Crucifers & Black Rot & 5.08 & [Genbank:NC_010688] & [31] \\
\hline X. campestris pv. raphani $756 C$ & Crucifers & Leaf Spot & 4.94 & [Genbank:NC_017271] & [32] \\
\hline X. campestris pv. vesicatoria (X. euvesicatoria) $85-10$ & Pepper \& tomato & Bacterial Spot A & 5.18 & [Genbank:NC_007508] & [33] \\
\hline X. citri pv. mangiferaeindicae LMG 941 & Mango & Bacterial Canker & 5.11 & [Genbank:NZ_CAHO00000000] & [34] \\
\hline X. fragariae LMG 25863 & Strawberry & Angular Leaf Spot & 4.18 & [Genbank:AJRZ00000000] & This study \\
\hline X. fuscans pv. aurantifolii ICPB 11122 & Citrus & Bacterial Canker B & 4.88 & [Genbank:NZ_ACPX00000000] & [35] \\
\hline X. fuscans pv. aurantifolii ICPB 10535 & Citrus & Bacterial Canker C & 5.01 & [Genbank:NZ_ACPY00000000] & [35] \\
\hline X. gardneri ATCC 19865 & Pepper \& tomato & Bacterial Spot D & 5.53 & [Genbank:NZ_AEQX00000000] & [24] \\
\hline X. oryzae pv. oryzae KACC 10331 & Rice & Bacterial Blight & 4.94 & [Genbank:NC_006834] & [36] \\
\hline X. oryzae pv. oryzae MAFF 311018 & Rice & Bacterial Blight & 4.94 & [Genbank:NC_007705] & [37] \\
\hline X. oryzae pv. oryzae PXO 99A & Rice & Bacterial Blight & 5.24 & [Genbank:NC_010717] & [38] \\
\hline X. oryzae pv. oryzicola BLS256 & Rice & Leaf Streak & 4.83 & [Genbank:NC_017267] & [32] \\
\hline X. perforans 91-118 & Tomato & Bacterial Spot C & 5.26 & [Genbank:NZ_AEQW00000000] & [24] \\
\hline X. sacchari NCPPB 4393 & Sugarcane, insects & & 4.9 & [Genbank:NZ_AGDB00000000] & [29] \\
\hline X. vesicatoria ATCC 35937 & Pepper \& tomato & Bacterial Spot B & 5.53 & [Genbank:NZ_AEQV00000000] & [24] \\
\hline
\end{tabular}

Alphabetic overview of the 26 Xanthomonas strains whose genomes were compared in this study, together with their associated natural hosts and diseases, genome size, Genbank records and relevant literature references, when available. Where the current consensus classification of the organism deviates from the given name in Genbank, the current consensus classification is given between brackets. ${ }^{\text {aDisputed in }}$ Vandroemme et al. [39]. 'only the Genbank records of the chromosomes are given. 


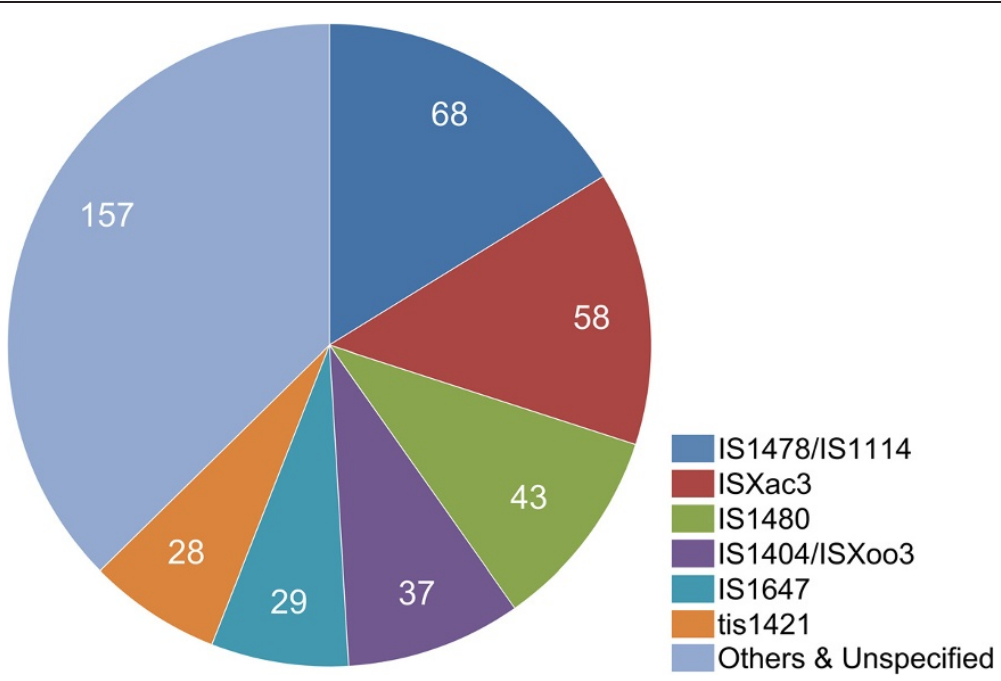

Figure 1 Insertion sequences (IS) families in the genome of $X$. fragariae LMG 25863. Overview of the most abundant Insertion Sequences (IS) families in the genome of $X$. fragariae, as annotated by the RAST online annotation pipeline.

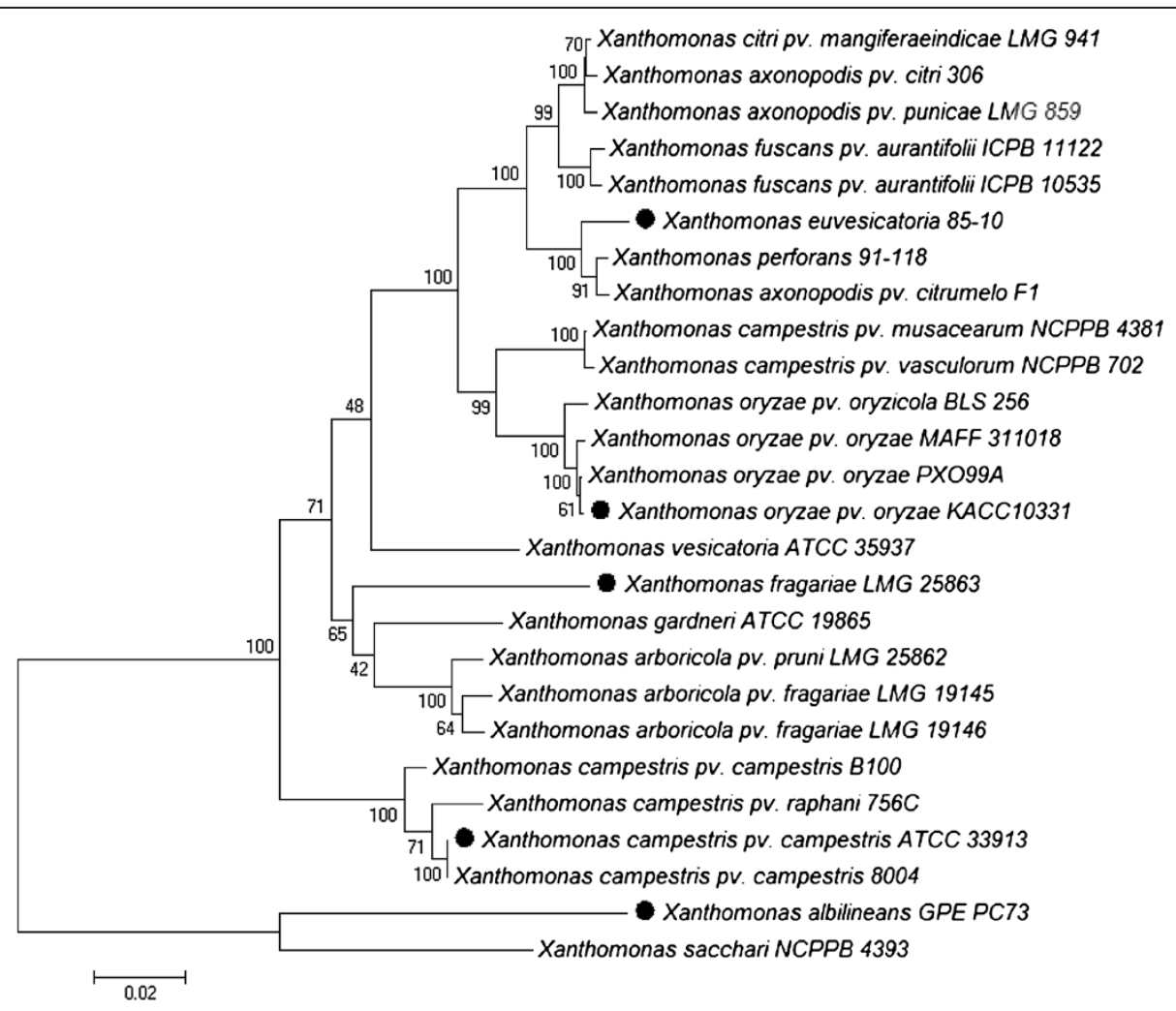

Figure 2 Relationship among 26 Xanthomonas genomes. Phylogenetic relationship among the 26 available Xanthomonas genomes based on the concatenation of partial gene sequences of $g y r B, r p o D$, atpD, dnaK and fyuA (in total about 3788 nucleotides per strain). The tree was generated with Mega 5 software using the Neighbour Joining algorithm with 1,000 bootstrap replicates. Bootstrap support for the groups is represented on the tree at the different nodes. Branch length is proportional to divergence, the 0.02 scale represents $2 \%$ difference. The 5 genomes used in the EDGAR comparative genome analysis are indicated by black circles $(\bullet)$. 


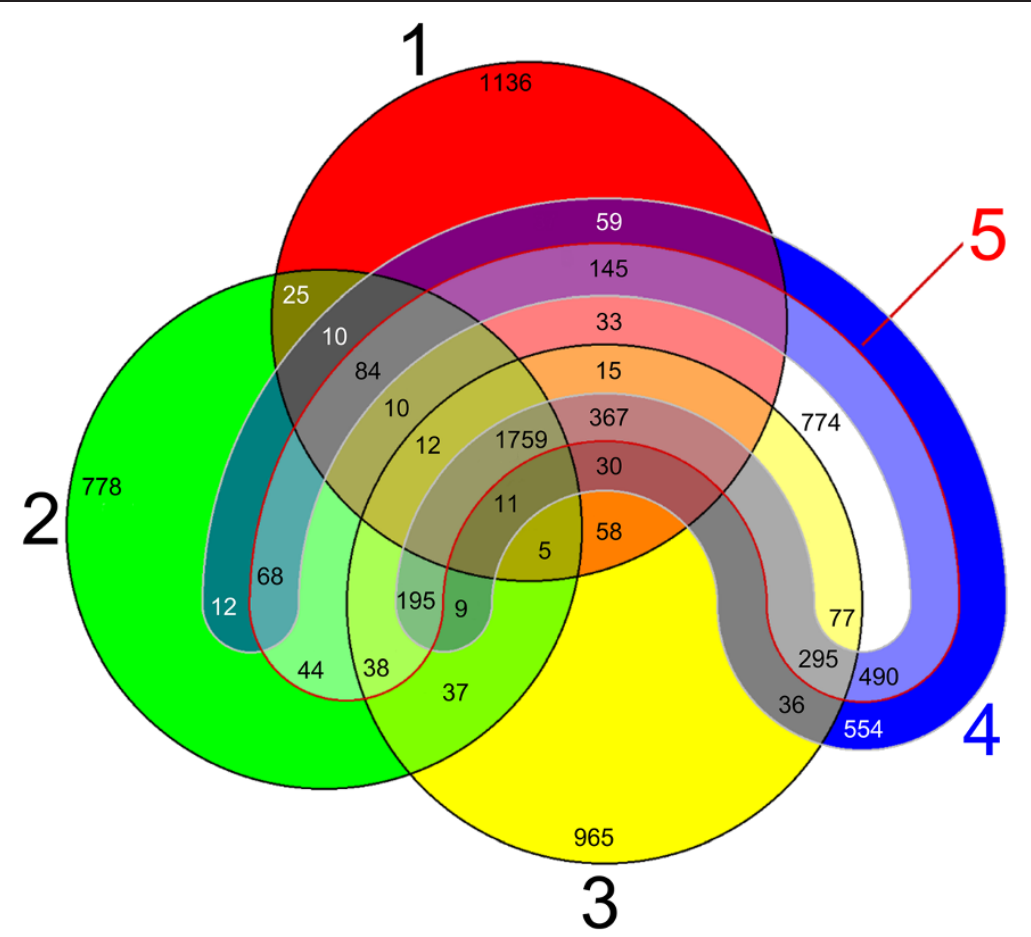

Figure 3 5-way genome comparison in EDGAR. Five-set Venn diagram constructed using EDGAR and visualizing the common gene pools among the genomes of 1) $X$. fragariae LMG 25863, 2) X. albilineans GPE PC73, 3) X. oryzae pv. oryzae KACC 10331, 4) X. campestris pv. campestris ATCC 33913 and 5) X. euvesicatoria 85-10.

pathway, the $s d k$ potassium transport system and the entire phenolics degradation pathway were uniquely missing in Xf.

\section{The $\mathrm{Xf}$ genome has a reduced TonB-dependent transporter set}

The EDGAR analysis suggested a substantial loss of TonB-dependent transporters (TBDT) in Xf, Xoo and Xalb. Therefore, we screened all 26 Xanthomonas genomes for homologs of 100 TBDT references (Additional file 2: Table S2). Overall, the average TBDT gene repertoire amounted to 56 homologs with a standard deviation of 14 . Then again only 27 homologs could be found in Xf, which was the second smallest TBDT repertoire after Xalb (26 homologs) (Figure 4). The Xoo and Xoc genomes had 34 to 40 homologs. The extensive TBDT repertoire in Xcc has been linked to niche diversity and carbohydrate scavenging in the oligotrophic conditions encountered during epiphytic survival [48]. In turn, the small TBDT sets in Xf, Xalb and the $X$. oryzae strains may be yet another adaptation to a stable and restricted niche.

\section{Xf has a reduced plant cell wall degrading enzyme set}

Observing the missing xylan degradation and ß-ketoadipate pathways in Xf, triggered us to study its Cell Wall Degrading Enzyme (CWDE) repertoire in greater detail. To this end, all 26 Xanthomonas genomes were screened for homologs of 46 CWDE references (Additional file 3: Table S3). The average number of pectinolytic, cellulolytic and hemicellulolytic enzyme homologs thus retrieved in each genome was 6,14 and 10 respectively, with standard deviations of 2, 2 and 3. The average total CWDE repertoire consisted of 31 homologs, with a standard deviation of 6 . With only 18 homologs, Xf revealed the smallest CWDE repertoire comprised of an apparently unreduced pectinolytic enzyme repertoire but with low numbers of cellulolytic (10 homologs) and hemicellulolytic (3 homologs) enzymes (Figure 5). Small CWDE repertoires were again also apparent in the genomes of Xalb (19 homologs), Xoc (20 homologs), and to a lesser extent in the three Xoo strains ( 25 homologs). For the 26 Xanthomonas genomes analysed, no clear correlation could be observed between the CWDE repertoires and their infection mode: only the XCC3534-like cellobiosidase appeared unique for vascular pathogens.

Despite the contribution of CWDEs to virulence, the reduced set of $\mathrm{Xf}$ does not necessarily make it a lesser pathogen. Smaller CWDE repertoires are typically found in biotrophic pathogens, who rely on precise breaching of the host cell wall during infection instead of extensive tissue destruction observed for necrotrophic pathogens [53]. One potential explanation for the reduced CWDE repertoire of Xf may be found in the concurrent absence of the $ß$-ketoadipate phenolics degradation pathway: 
Table 3 Major virulence related gene regions in the 5 Xanthomonas genomes compared in the EDGAR analysis

\begin{tabular}{|c|c|c|c|c|c|}
\hline Gene cluster & $X f$ & Xcc & Xcv & Xoo & Xalb \\
\hline gum (gumB/gumM) & O1K_14575/O1K_14520 & XCC2454/XCC2443 & XCV2787/XCV2776 & X003179/X003168 & Absent \\
\hline hrp (hpa2/hpaB) & O1K_02671/O1K_02566 & XCC1241/XCC1220 & XCV0441/XCV0411 & X000096/X000075 & Absent \\
\hline LPS (metB/etfA) & O1K_19071/O1K_18996 & XCC0598/XCC0619 & XCV3725/XCV3711 & X000778/XО00790 & XALc_2712/XALc_2699 \\
\hline$r p f(r p f A / r p f G)$ & O1K_08102/O1K_08072 & XCC1860/XCC1854 & XCV1924/XCV1917 & X002865/X002871 & XALC_1349/XALC_1345 \\
\hline$x \operatorname{cs}(x \operatorname{cs} C / x \operatorname{cs} N)$ & Absent & XCC3416/XCC3426 & XCV0755/XCV0765 & Absent & Absent \\
\hline xps (xpsE/xpsD) & O1K_16416/O1K_16366 & XCC0660/XCC0670 & XCV3658/XCV3668 & X000847/X000857 & XALC_2654/XALC_2664 \\
\hline T4SS (virD4/virB6) & O1K_12781/O1K_12736 & XCC2483/XCC2474 & XCV2810/XCV2807 & Absent & XALC_1842/XALC_1835 \\
\hline Flagellum (fliA/flgM) & O1K_18068/O1K_17833 & XCC1906/XCC1955 & XCV1977/XCV2036 & X002621/X002836 & XALc_1379/XALC_1431 \\
\hline
\end{tabular}

i) the gum gene cluster for extracellular polysaccharide synthesis, ii) the hrp gene cluster for Type III secretion, iii) the gene cluster for lipopolysaccharide (LPS) synthesis, iv) the rpf gene cluster for regulation of pathogenicity, the Type II Secretion System coding gene clusters v) xcs and vi) xps, vii) the gene cluster for the most common Type IV Secretion System in Xanthomonas and viii) the flagellar biosynthesis genes. Gene clusters retrieved in each genome are labeled with the locus tags of their respective first and last genes (names given between parentheses). ${ }^{\mathrm{a}}$ virD4 absent in this gene region, but replaced by divergent homolog elsewhere in the genome, ${ }^{b}$ virB5 and virB6 missing, ${ }^{C}$ all genes except virD4, virB8 and virB9 missing.

strawberry plant tissue is rich in phenolics [54] and many contribute to plant defence as phytoanticipins or phytoalexins, which are often released when plant cell integrity is compromised [55]. Therefore, one could hypothesize that one way for Xf to survive long-term residence in its potentially toxic host is to avoid extensive tissue damage.

\section{Xf exhibits a distinct T3SE repertoire and several putatively new effectors}

Because several Xf-exclusive CDS in the EDGAR analysis showed similarity with Type III Secretion Effector (T3SE) genes, we compared the T3SE genes of Xf with those of the other 25 Xanthomonas genomes. Classifying the Xfeffectors within the currently defined effector-families [56], however, was challenging. Some effector families contained clearly distinct subgroups with lower than $70 \%$ inter-subgroup pairwise protein sequence similarities, as indicated here for XopA (Figure 6). A more restrictive definition and further subdivision of the current T3SEfamilies could improve the classification. For now, we retained the classification as defined by White et al. (2009) [56], except for XopAG, and applied a general cut-off of $60 \%$ pairwise protein sequence similarity within a given effector family. For XopAG we suggest the division into two subfamilies: XopAG1 and XopAG2, with [Genbank:ZP_10262207] and [Genbank:ZP_10263166] as respective reference sequences, encountered in the genome of $X$. axonopodis pv. punicae LMG 859. The Xfeffector gene [Genbank:O1K_00020] was unambiguously classified in XopAG2 (Figure 7). Using the 60\% cut-off rule, we identified homologs of 23 known Xanthomonas T3SEs in Xf, with two homologs for XopX (Table 5). Presence of at least one XopAD homolog and multiple $X o p P$ homologs was suggested, but could not be confirmed due to incomplete genome assembly.

Comparison of the effector gene repertoire identified in $\mathrm{Xf}$ and in the other 25 Xanthomonas genomes is shown (Additional file 4: Table S4). For simplicity, multiple homologs of a certain effector class within a single genome were marked only once. Transcription Activator-Like Effectors (TALEs) were not included in the comparison because Xf did not appear to contain any, and also TALEs are distinct from the other effectors in both coding sequences and function [57]. Among the 23 hrp-positive genomes, the average T3SE repertoire consisted of 23 different families, with a standard deviation of 5 (Figure 8). Explicit small T3SE repertoires were observed in $X$.

Table 4 Noteworthy gene-regions missing in X. fragariae LMG 25863

\begin{tabular}{|c|c|c|c|c|c|}
\hline Gene cluster & $X f$ & Xcc & Xcv & Xoo & Xalb \\
\hline Glyoxylate shunt & Absent & XCC0232/XCC0240 & XCV0257/XCV0267 & Absent & Absent \\
\hline Phenolics Degradation I & Absent & XCC0354/XCC0363 & XCV0367/XCV0377 & Absent & XALC_3034/XALC_3040 \\
\hline Phenolics Degradation II & Absent & XCC0366/XCC0373 & XCV0380/XCV0387 & X000481/X000488 & XALC_3021/XALC_3031 \\
\hline Potassium Transport & O1K_06922 ${ }^{\mathrm{a}}$ & XCC0702/XCC0706 & XCV0808/XCV0812 & X003842/X003846 & XALC_2828/XALC_2832 \\
\hline Xylan degradation I & Absent & XCC2826/XCC2828 & XCV3145/XCV3147 & X001260/X001262 & XALC_3147/XALC_3149 \\
\hline Xylan degradation III & Absent & XCC4102/XCC4107 & XCV4333/XCV4338 & X004419/X004424 & XALC_0057/XALC_0062 \\
\hline Xylan degradation III & Absent & XCC4117/XCC4122 & XCV4357/XCV4364 & X004427/X004433 & XALC_0035/XALC_0040 \\
\hline
\end{tabular}

Gene regions found absent in the genome of $X$. fragariae LMG 25863, together with their occurrence in the complete genomic sequences of 4 other Xanthomonas species compared in EDGAR: i) the glyoxylate shunt pathway genes, ii) the genes coding for a phenolics degradation pathway, iii) the structural genes of a potassium transporter and iv) the three loci for xylan degradation. Gene regions retrieved from each genome are labeled with the locus tags of their respective

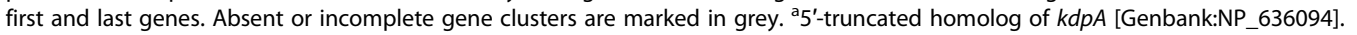




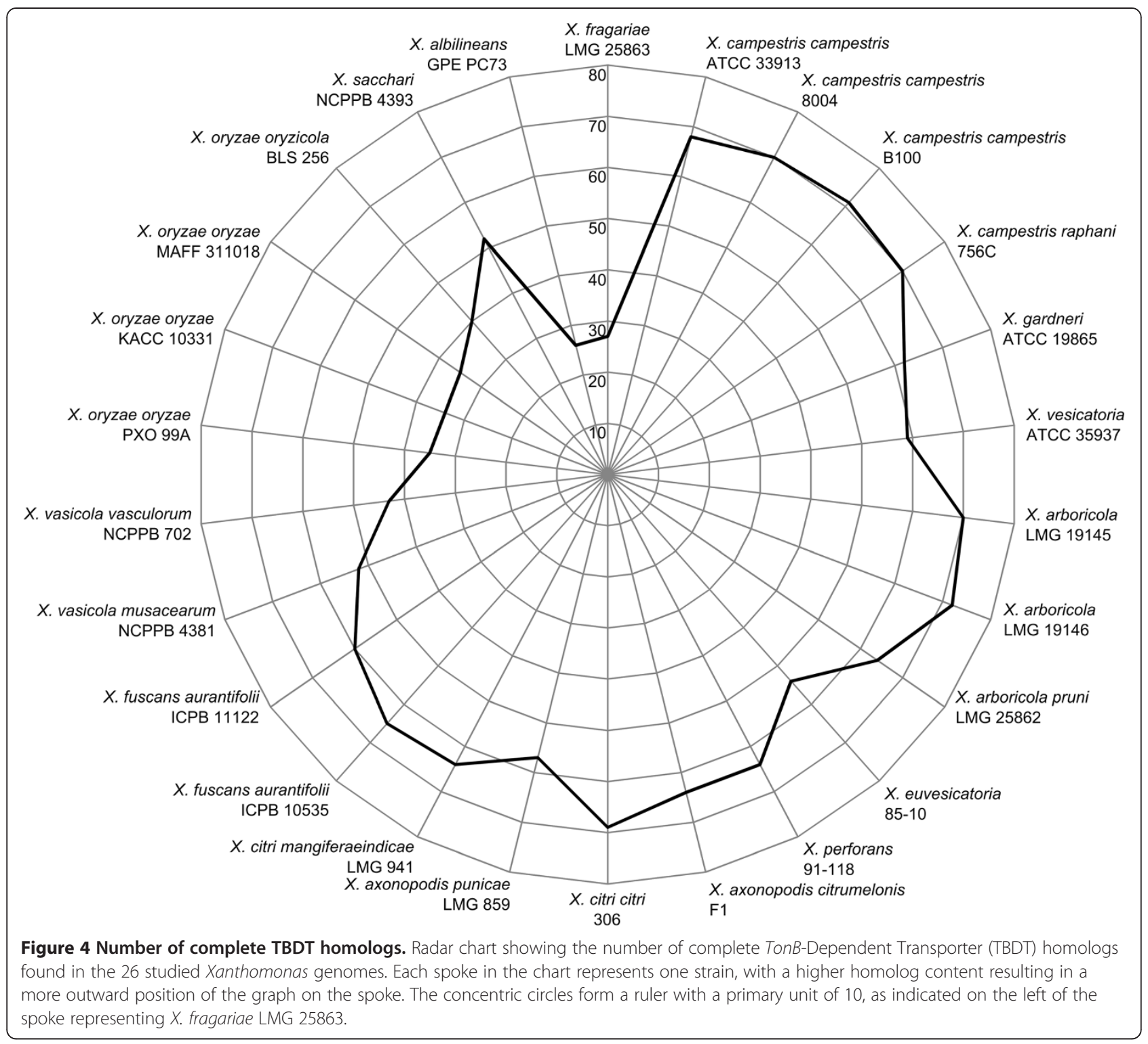

campestris pv. raphani 756C (13 effectors) and in $X$. arboricola LMG 19146 (6 effectors) [39], while Xcv revealed the largest repertoire with 31 effectors.

Although the T3SE repertoire of Xf seemed averagesized ( 25 effectors), it distinguished itself by the presence of multiple rare effectors: XopB, XopC1, XopE4, XopZ2, XopAF and XopAS. This distinct T3SE repertoire in Xf was also evident from the isolated position of $\mathrm{Xf}$ in a Neighbor Joining split network based on binary representations of the T3SE repertoires found among all 23 hrp-positive genomes (Figure 9). Interestingly, the general topology of the T3SE-based network correlated well with the MLSA based phylogenetic tree shown before, suggesting that at least a fraction of the T3SE repertoire was acquired early and evolved slowly during the formation of the major lineages within the genus.
In addition to this unique "known" T3SE repertoire, the $\mathrm{Xf}$ genome also revealed several putative new effectors (Table 6). Three putative T3SEs in Xf showed low homology with the known Xanthomonas effectors XopC, XopE and XopAD: [Genbank:O1K_18811] showed highest pairwise similarity $(66.6 \%)$ with a T3SE found in the genus Ralstonia, [Genbank:01K_20482] showed 56.4\% similarity to an unidentified protein in Mesorhizobium, and [Genbank:O1K_11082] showed up to $78.5 \%$ pairwise similarity with an unidentified protein in X. gardneri ATCC 19865. Nine other putative T3SEs in Xf showed distant homology with both XopD and PsvA, a T3SE family in Acidovorax and Pseudomonas contributing to host specificity, plant defence suppression and in planta pathogen proliferation [58]. Although the function of these putative new T3SEs still needs to be confirmed, the likely Plant-Inducible- 

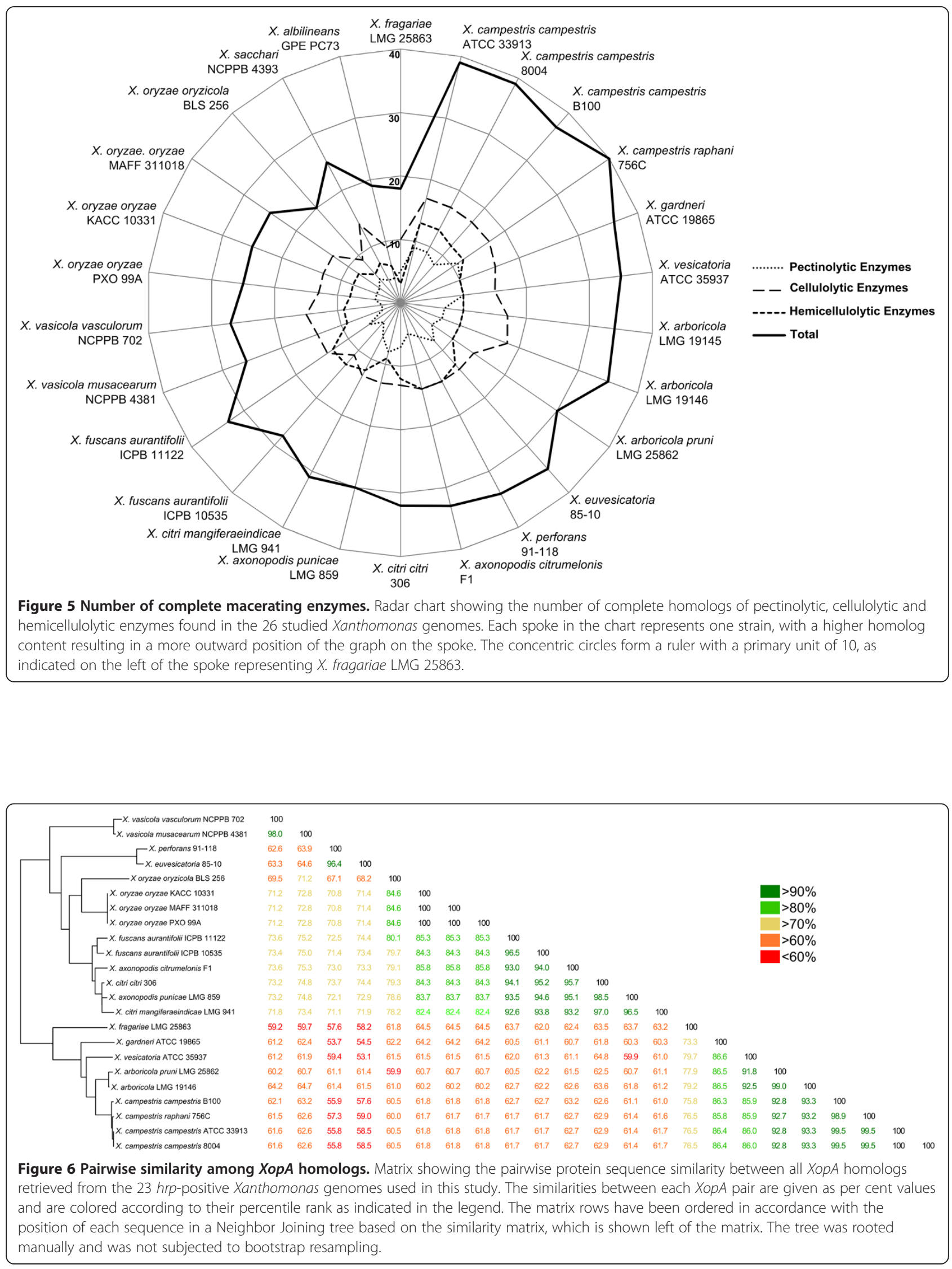


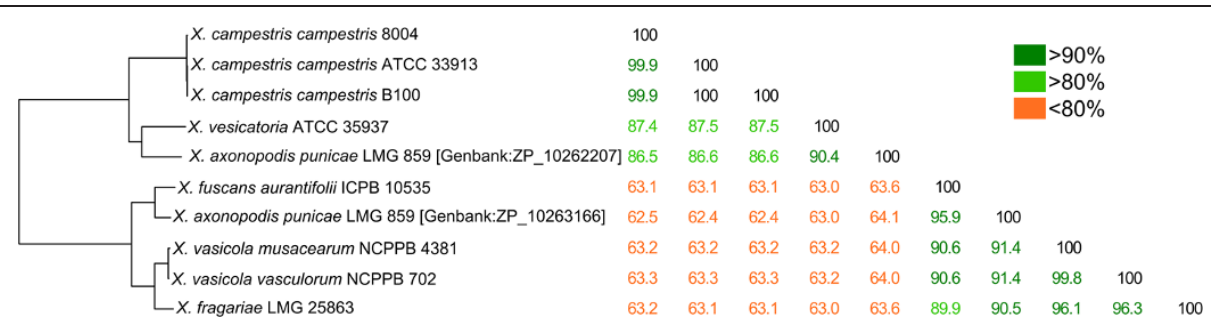

Figure 7 Pairwise similarity among XopAG homologs. Matrix showing the pairwise protein sequence similarity between all XopAG homologs retrieved from the 23 hrp-positive Xanthomonas genomes used in this study. The similarities between each XopAG pair are given as per cent values and are colored according to their percentile rank as indicated in the legend. The matrix rows have been ordered in accordance with the position of each sequence in a Neighbor Joining tree based on the similarity matrix, which is shown left of the matrix. The tree was rooted manually and was not subjected to bootstrap resampling. The locus tags of both XopAG homologs retrieved in the genome sequence of X. axonopodis pv. punicae LMG 859 are given between rectangular brackets.

Table 5 Known type III secretion effectors of X. fragariae LMG 25863

\begin{tabular}{|c|c|c|c|}
\hline Effector & Locus tag & $\begin{array}{l}\text { Best match for } \\
\text { Xf- sequence }\end{array}$ & $\begin{array}{l}\text { Worst match among } \\
\text { other sequences }\end{array}$ \\
\hline AvrBs2 & [Genbank:O1K_12410] & $92.3 \%$ & $72.5 \%$ \\
\hline $\mathrm{Hpa2/HpaH}$ & [Genbank:O1K_02671] & $87.6 \%$ & $79.0 \%$ \\
\hline HpaA & [Genbank:O1K_02586] & $84.0 \%$ & $68.2 \%$ \\
\hline XopA/hpa1 & [Genbank:01K_02666] & $79.7 \%$ & $53.1 \%$ \\
\hline XopB & [Genbank:O1K_11187] & $84.6 \%$ & $88.5 \%$ \\
\hline XopC1 & [Genbank:O1K_14874] & $97.4 \%$ & $99.9 \%$ \\
\hline XopD & [Genbank:O1K_16938] & $67.7 \%$ & $78.2 \%$ \\
\hline XopE4 & Contig19 (17160..18326) & $97.6 \%$ & $100.0 \%$ \\
\hline XopF1 & [Genbank:O1K_02551] & $82.6 \%$ & $75.3 \%$ \\
\hline XopF2 & [Genbank:01K_06487] & $63.1 \%$ & $55.7 \%$ \\
\hline XopK & [Genbank:O1K_18791] & $85.6 \%$ & $72.0 \%$ \\
\hline XopL & [Genbank:O1K_16566] & $66.1 \%$ & $60.7 \%$ \\
\hline XopN & [Genbank:O1K_10027] & $87.3 \%$ & $73.4 \%$ \\
\hline Xоp $P^{a}$ & $\begin{array}{l}\text { [Genbank:O1K_11182, Genbank:O1K_11197, Genbank:O1K_11202, } \\
\text { Genbank:O1K_11207, Genbank:O1K_11212]; Contig64; Contig67 }\end{array}$ & & \\
\hline XopQ & [Genbank:O1K_15074] & $87.1 \%$ & $71.4 \%$ \\
\hline XopR & [Genbank:O1K_01999] & $75.7 \%$ & $57.4 \%$ \\
\hline XopV & [Genbank:O1K_05602] & $77.5 \%$ & $71.6 \%$ \\
\hline XopX & [Genbank:01K_04266] & $83.3 \%$ & $68.1 \%$ \\
\hline$X_{o p} X^{b}$ & [Genbank:O1K_04271, Genbank:O1K_04281] & $85.1 \%$ & $68.1 \%$ \\
\hline XopZ2 & [Genbank:O1K_02556] & $87.3 \%$ & $88.5 \%$ \\
\hline XopAD ${ }^{\mathrm{a}}$ & [Genbank:O1K_14315]; Contig24 (1..5097); Contig57; Contig92 (89708..96529) & & \\
\hline ХорAE & [Genbank:O1K_08322] & $69.6 \%$ & $84.7 \%$ \\
\hline XорAF & [Genbank:O1K_18806] & $72.5 \%$ & $50.4 \%$ \\
\hline XopAG2 & [Genbank:O1K_00020] & $96.3 \%$ & $90.6 \%$ \\
\hline ХорАM & [Genbank:O1K_07544] & $87.3 \%$ & $80.5 \%$ \\
\hline XopAS ${ }^{\complement}$ & [Genbank:O1K_11585] & ND & ND \\
\hline
\end{tabular}

Overview of known type III secretion effector homologs retrieved in X. fragariae LMG 25863, together with their locus tags in the whole-genome sequences. Incomplete or un-annotated loci are marked with the label of the coding contig and coding nucleotide range, when applicable. As an indication of the diversity within each effector class, the pairwise protein sequence similarity between the $X$. fragariae homolog and its best match found among the other Xanthomonas genomes is given, and the worst sequence match among all remaining effector sequences. ${ }^{\mathrm{a}}$ Partial sequences because of incomplete genome assembly, ${ }^{\mathrm{b}} \mathrm{O} 1 \mathrm{~K} \_04281$ is a suspected incorrect double of O1K_04271 caused by erroneous sequence assembly, ' no other complete homologs in Xanthomonas. ND, not determined. 


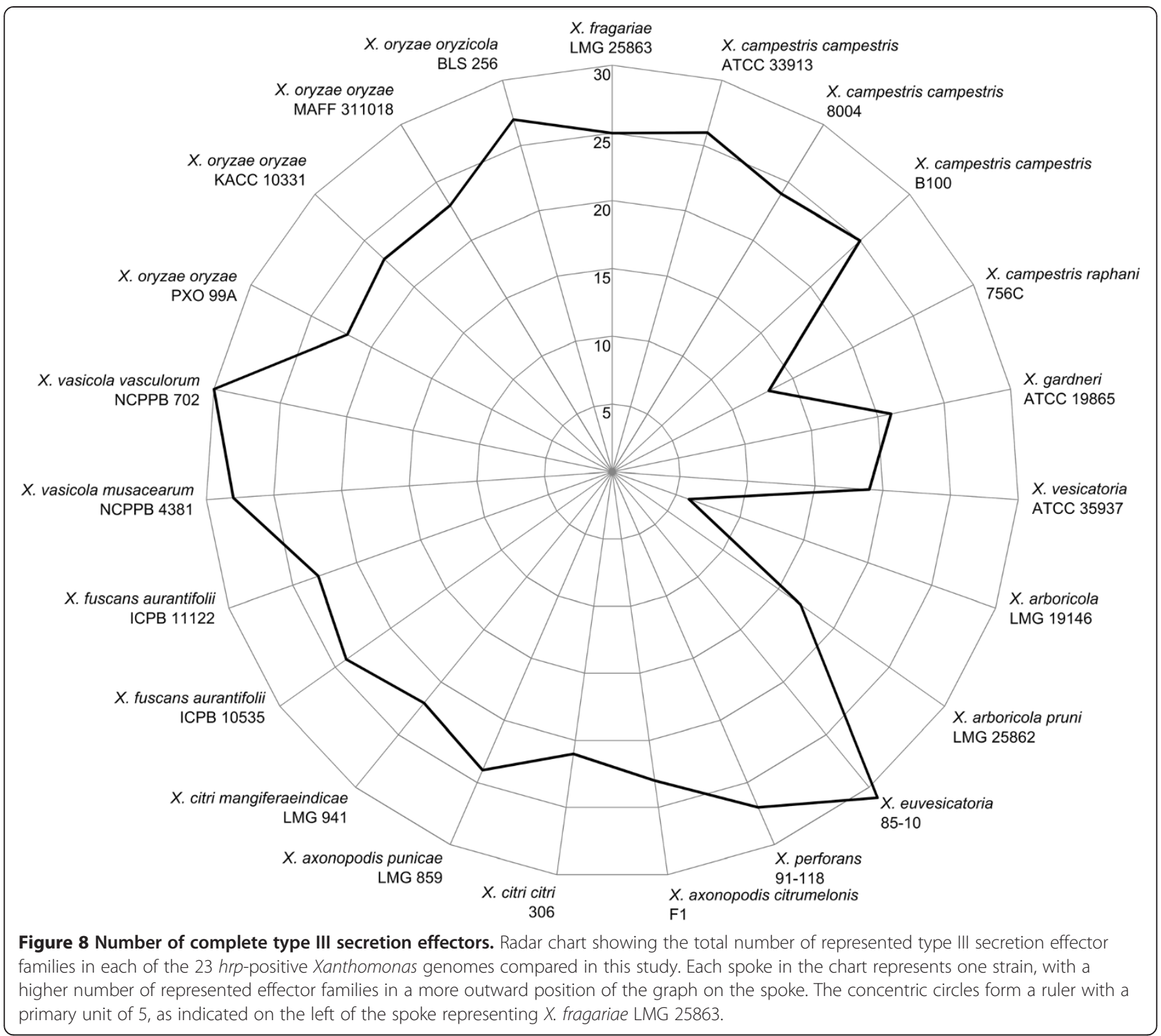

Promoter (PIP) sequences [59], frequently found in the vicinity of their coding sequences, suggest virulence-related functions for these proteins. The low\%GC value observed in 7 of these coding sequences might suggest that they were acquired through horizontal gene transfer (Table 6).

\section{Xf harbours a Type VI secretion system similar to $X$. oryzae}

Two loci shared between Xf and Xoo in the EDGAR analysis appeared to code for structural elements of a Type VI secretion system (T6SS). Coding sequences for putative Vgr protein-like T6SS effectors were encountered in the $\mathrm{Xf}$ genome, although their exact number and sequence could not be established due to incomplete assembly. The T6SS is the most recently found secretion system in gram-negative bacteria, and several distinct types are widely distributed among the Proteobacteria [60]. In contrast to their common structure, which is analogous to the injection apparatus of bacteriophages, the specific roles of each of these distinct T6SSs are still obscure: some systems were shown to contribute to the modification of eukaryotic hosts within both pathogenic and symbiotic relationships, while others were linked to inter-bacterial activity during the struggle for niche dominance [61,62]. All 26 Xanthomonas genomes were searched for the presence of T6SSs using a widely retained T6SS-related protein class (COG3519) as bait [63], which revealed the presence of three distinct T6SSs within the genus (Figure 10). The T6SS of Xf appeared highly similar to one of the two T6SSs that were found in the $X$. oryzae genomes. This distinct, previously thought $X$. oryzae-exclusive, T6SS has been correlated with plant 


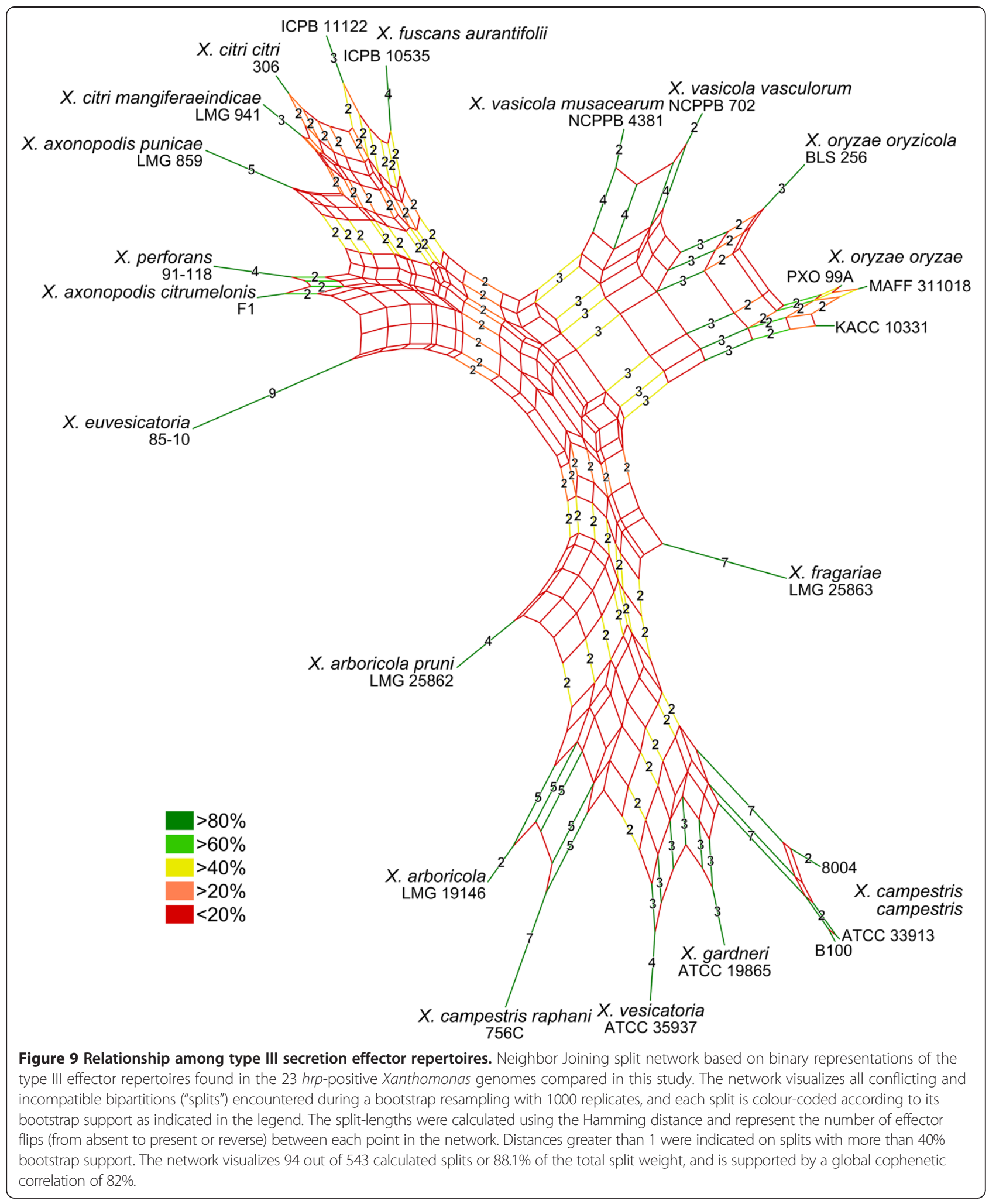

host specialization because of its similarity with the T6SS found in plant pathogens like Ralstonia solanacearum and Pseudomonas syringae [60]. The same study grouped the other two T6SSs that were observed here, in a widely distributed T6SS class present in both animal and plant pathogens, suggesting a broader functionality. Of course, this in-silico based hypothesis would need further experimental confirmation. 
Table 6 Potential new type III secretion effectors found in X. fragariae LMG 25863

\begin{tabular}{|c|c|c|c|c|c|c|c|c|c|c|}
\hline \multicolumn{5}{|c|}{ General characteristics } & \multicolumn{3}{|c|}{$\begin{array}{c}\text { Most closely related known } \\
\text { Xanthomonas T3SE }\end{array}$} & \multicolumn{3}{|c|}{ Best genbank match } \\
\hline Locus & $\begin{array}{l}\text { Moved start-codon } \\
\text { compared to } \\
\text { PGAAP annotation }\end{array}$ & $\begin{array}{l}\text { Protein } \\
\text { length }\end{array}$ & $\% G C$ & Putative PIP & $\begin{array}{l}\text { Effector } \\
\text { class }\end{array}$ & $\begin{array}{l}\text { Best match } \\
\text { for Xf }\end{array}$ & $\begin{array}{l}\text { Worst match amongst } \\
\text { the sequences within } \\
\text { the effector class }\end{array}$ & Locus & Organism & $\begin{array}{l}\text { Similarity with } \\
\text { Xf-sequence }\end{array}$ \\
\hline [Genbank:O1K_18811] & & $424 \mathrm{AA}$ & 52 & & XopC2 & $52.8 \%$ & $94.4 \%$ & [Genbank:CCA89217] & Ralstonia & $66.6 \%$ \\
\hline [Genbank:O1K_11082] & $147 \mathrm{bp}$ to 5 ' side & $327 \mathrm{AA}$ & 64 & $\begin{array}{l}\text { ttcgcaaacgcgtgcatgctgttggc- } \\
(\mathrm{N})_{323}-\mathrm{TTG}\end{array}$ & XopE3 & $55.4 \%$ & $97.8 \%$ & [Genbank:ZP_08184849] & X. gardneri & $78.5 \%$ \\
\hline [Genbank:O1K_20482] & $492 \mathrm{bp}$ to 5 ' side & $2578 \mathrm{AA}$ & 64 & $\begin{array}{l}\text { ttggcggccacgtgccgacgttgcc- } \\
(\mathrm{N})_{244} \text {-ATG }\end{array}$ & XopAD & $53.4 \%$ & $86.0 \%$ & [Genbank:ZP_09295361] & Mesorhizobium & $56.4 \%$ \\
\hline [Genbank:O1K_01564] & $507 \mathrm{bp}$ to 5 ' side & $570 \mathrm{AA}$ & 56 & $\begin{array}{l}\text { ttcggcaaacccactacgecttcgc- } \\
\left(\mathrm{N}_{222}-\mathrm{ATG}\right.\end{array}$ & XopD & $46.9 \%$ & $78.2 \%$ & [Genbank:EGH27374] & Pseudomonas & $55.7 \%$ \\
\hline $\begin{array}{l}\text { [Genbank:01K_01569, } \\
\text { Genbank: O1K_01579] }\end{array}$ & $975 \mathrm{bp}$ to 5 ' side & $580 \mathrm{AA}$ & 56 & $\begin{array}{l}\text { ttcggcaaacccactacgccttcgc- } \\
(\mathrm{N})_{222}-\mathrm{ATG}\end{array}$ & XopD & $47.8 \%$ & $78.2 \%$ & [Genbank:EGH27374] & Pseudomonas & $54.7 \%$ \\
\hline [Genbank:O1K_01589] & $399 \mathrm{bp}$ to $5^{\prime}$ side & $583 \mathrm{AA}$ & 57 & $\begin{array}{l}\text { ttcggcaaagccgctacgccttcgc- } \\
\qquad(\mathrm{N})_{206} \text {-ATG }\end{array}$ & XopD & $47.9 \%$ & $78.2 \%$ & [Genbank:EGH27374] & Pseudomonas & $55.1 \%$ \\
\hline [Genbank:O1K_02164] & 453 bp to 5 ' side & $666 \mathrm{AA}$ & 56 & $\begin{array}{l}\text { ttcggcaagcccgctacgecttcgc- } \\
(\mathrm{N})_{193} \text {-ATG }^{-A T}\end{array}$ & XopD & $49.3 \%$ & $78.2 \%$ & [Genbank:EGH27374] & Pseudomonas & $53.2 \%$ \\
\hline [Genbank:O1K_03146] & 633 bp to 5' side & $860 \mathrm{AA}$ & 57 & $\begin{array}{l}\text { ttcggcaaacctgctacgccttcgc- } \\
(\mathrm{N})_{156} \text {-ATG }\end{array}$ & XopD & $52.0 \%$ & $78.2 \%$ & [Genbank:EGH27374] & Pseudomonas & $47.8 \%$ \\
\hline [Genbank:O1K_03991] & 342 bp to $5^{\prime}$ side & $584 \mathrm{AA}$ & 55 & & XopD & $47.9 \%$ & $78.2 \%$ & [Genbank:EGH27374] & Pseudomonas & $54.0 \%$ \\
\hline [Genbank:O1K_13828] & 891 bp to 5' side & $675 \mathrm{AA}$ & 55 & $\begin{array}{l}\text { ttcggcaaacccgctacgccttcgc- } \\
(\mathrm{N})_{210^{-}} \text {ATG }\end{array}$ & XopD & $47.5 \%$ & $78.2 \%$ & [Genbank:EGH27374] & Pseudomonas & $51.6 \%$ \\
\hline [Genbank:O1K_20327] & 246 bp to 5 ' side & $619 \mathrm{AA}$ & 56 & $\begin{array}{l}\text { ttcggcaaacccgttacgccttcgc- } \\
(\mathrm{N})_{224} \text {-ATG }\end{array}$ & XopD & $47.9 \%$ & $78.2 \%$ & [Genbank:EGH27374] & Pseudomonas & $55.8 \%$ \\
\hline
\end{tabular}

Inducible-Promosser (PIP) type IIl secretion effectors in X. fragariae LMG 25863 together with their Genbank accessions, protein length in amino acids, \%GC-content of the coding DNA sequences, and possible Plantnew Xf-effector and the most closely related Xanthomonas effector class is compared with the lowest pairwise similarity observed within this effector class. Finally, the accession number of the best protein blast match in Genbank for each putative new Xf-effector is given together with the organism it comes from, and its pairwise protein sequence similarity with the Xf-effector. ${ }^{\mathrm{a} O 1 \mathrm{~K} \_01579}$ is a possible incorrect double of

O1K_01569, created by incorrect sequence assembly. 


\section{Evidence of considerable horizontal gene transfer and a CRISPR in Xf}

In addition to some virulence genes that are possibly acquired by Horizontal Gene Transfer (HGT) and IS elements, other evidence of HGT-exposure could be found in the $\mathrm{Xf}$ genome. The IS-content appeared exceptionally abundant in Xf. While IS abundance is a common feature of Xanthomonas genomes, exceptionally high IS content was previously reported for the three Xoo strains and the Xoc strain [32,36-38]. There, it was interpreted as a result of the consistent association of these strains with rice: the stable environment would have alleviated the selective pressure of many genes, allowing their disruption by IS. A similar process could be envisioned for Xf. Conversely, it has also been described as an important source of genome plasticity in $X$. oryzae and a cause of the genotypic diversity within the species $[32,38]$. This seems to conflict with the restricted genotypic diversity reported for Xf. Perhaps the relatively young practice of formal plant breeding in strawberry cultivation (18th-19th century AD) [64] compared to the ancient domestication of rice (7000$4000 \mathrm{BC})$ [65] has to be considered.

Possible HGT-related CDS in Xf were a set of phage coding genes ([Genbank:O1K_11280] to [Genbank:O1 K_11410]), nine toxin-antitoxin (TA) modules (Table 7) [66], and nine contigs with a total sequence length of $25 \mathrm{~Kb}$ exhibiting more than $90 \%$ overall DNA sequence identity with the $27 \mathrm{~Kb}$ Plasmid II of $X$. albilineans GPE PC73. The latter nine contigs mainly coded for the structural elements of a second, phylogenetic distinct T4SS, and plasmid replication functions. Although this raised the possibility of an autonomous plasmid in Xf, so far we were unable to identify or isolate any plasmid DNA from the sequenced strain (data not shown).

Another HGT-related CDS in Xf with a potential virulence related function, [Genbank:O1K_06242], coded for a 2485aa putative Repeats-in-toxin (RTX) exoprotein [67]. Its low\%GC (54\%) and the presence of IS elements directly up and downstream seem to indicate that it was acquired through HGT. 
Table 7 Toxin-antitoxin modules in X. fragariae LMG 25863

\begin{tabular}{ccc}
\hline Toxin & Antitoxin & Putative toxin/antitoxin-system \\
\hline [Genbank:O1K_03731] & [Genbank:O1K_03726] & RelE/RelB \\
[Genbank:O1K_03776] & [Genbank:O1K_03771] & HigB/HigA \\
[Genbank:O1K_04356] & [Genbank:O1K_04361] & ParD/ParE \\
[Genbank:O1K_07102] & [Genbank:O1K_07097] & DinJ/YafQ \\
[Genbank:O1K_07172] & [Genbank:O1K_07177] & VapB/NapC \\
[Genbank:O1K_12891] & [Genbank:O1K_12886] & RelE/StbE \\
[Genbank:O1K_17078] & [Genbank:O1K_17073] & CcdB/CcdA \\
[Genbank:O1K_04456] & [Genbank:O1K_04461] & Phd/Doc \\
[Genbank:O1K_04466] & [Genbank:O1K_04471] & MazE/MazF \\
\hline
\end{tabular}

Genbank accession numbers of toxin and antitoxin sequences identified in X. fragariae LMG 25863 by Genbank protein sequence blast queries together with their putative toxin-antitoxin module family.

Finally, the Xf genome revealed a Clustered Regularly Interspaced Short Palindromic Repeats (CRISPR)-region comprised of 6 CRISPR associated (cas) genes of the so-called Ypest ("Yersinia pestis") subtype ([Genbank: O1K_01919] to [Genbank:O1K_01944]), a 121 bp long AT-rich leader sequence and a CRISPR containing 36 identical repeats and 36 spacers. A second, smaller locus containing an additional 4 repeats and 3 spacers was also found, although the last repeat in this locus was degenerated. Among all other studied Xanthomonas genomes, cas-genes of the Ypest-subtype were also found in Xalb and X. campestris pv. raphani 756C (Xcr). Moreover, the associated CRISPR repeat sequence in Xf (GTTCACTGCCGCGTAGGCAGCTCAGAAA) was identical to that of Xcr, and diverged only one nucleotide from that of Xalb (GTTCACTGCCGTGTAGGCAGCT CAGAAA). CRISPR regions were recently recognized as a prokaryotic adaptive immune system against invading DNA molecules, with functional analogy to the RNA interference (RNAi) pathways in eukaryotes [68].

\section{Conclusion}

The draft genome sequence of Xf provided valuable insight in its general and more specific pathogenicityrelated gene content. Although the current total contig size of $4.2 \mathrm{Mb}$ is not definite, the sheer amount of missing gene homologs in $\mathrm{Xf}$ is sufficient evidence for a significant genome reduction. A similar "convergent genome erosion" was already reported for X. albilineans and X. oryzae pv. oryzae, and ascribed to their restricted lifestyle within the xylem vessels of their hosts [25]. A similar genome reduction was found here in $\mathrm{Xf}$ and also in $\mathrm{X}$. oryzae pv. oryzicola BLS256, which are two non-vascular leaf pathogens. Therefore, it may be more accurate to ascribe the convergent genome reduction of these Xanthomonas species to their endophytic lifestyle and typically to their commitment to a single host. Similar to earlier comparative genomic studies within Xanthomonas [30,45], we were unable to find clear determinants for host or tissue specificity. Perhaps this specificity is the result of a more complex interplay between different genes or, of a subtle sequence variation within a small set of conserved genes. Alternatively, clear host or tissue determinants may still remain hidden within the substantial group of proteins for which we currently have no clear molecular function, or in uncharacterised functional RNAs.

Based on the data presented here, one could hypothesize an evolutionary process for $\mathrm{Xf}$ that is reminiscent of the model that was recently presented for some dangerous epidemic bacteria of humans [69]. During an initial period of intense horizontal gene transfer experienced by the more generalist ancestor of $\mathrm{Xf}$, acquirement of certain heterologous host-specificity factors would have allowed it to colonize the strawberry leaf apoplast and thus escape antagonists and environmental threats. This transition from a dynamic to a stable environment would subsequently have triggered the observed genome reduction: useless or redundant features, especially metabolic, perceptive and regulatory functions, were allowed to degrade and eventually were lost. At some point, the progressing genome erosion resulted in the effective metabolic "entrapment" of Xf within the strawberry plant, excluding it from other hosts or more general epiphytic or saprophytic lifestyles. Because of Xf's increasing spatial and phylogenetic isolation, the initially intense horizontal gene transfer would have abated, a process that was perhaps hastened by the acquirement of the CRISPR region. Meanwhile, mobile genetic elements which conferred a selective advantage to Xf would have become permanently incorporated in the genome. This evolutionary process would finally have resulted in the genotypical and phenotypical distinct, mainly endophytic, biotrophic and strawberry-specific Xf known today. The eventual necrosis of the typical water-soaked angular leaf spots associated with Xf would not be in conflict with this hypothesis: it could be the manifestation of an eventual 
breakthrough of the plant defence, or merely the collapse of an overburdened plant cellular system.

Of course, many of the in-silico based hypotheses presented here should be tested and confirmed by further experimental data. In our opinion, the most appealing matters for future research are i) the molecular and functional characterization of the putatively new PsvAlike T3SEs, ii) the exact function of the T6SS in Xf and other Xanthomonas, and iii) the delicate endophytic existence of $\mathrm{Xf}$, sensitive to toxic compounds inside the strawberry plant cells.

\section{Methods}

Strain selection, culture conditions and DNA preparation The selected Xf strain, LMG 25863, was isolated as GBBC-Xf 920 in 2002 from clear angular leaf spots on strawberry leaves at the Institute for Agricultural and Fisheries Research (ILVO) in Belgium. Since then, it has been applied in the development of a real-time PCR detection method for Xf [70], served as Xf reference in a study of $X$. arboricola pv. fragariae [39] and as parental strain in the development of a green fluorescent $\mathrm{Xf}$ mutant (unpublished). It was deposited at the BCCMLMG culture collection at the time of whole genome sequencing. For genomic DNA preparation, the cryogenically stored $\mathrm{Xf}$ strain was resuscitated by incubation on Wilbrinck-N agar medium [71] at $28^{\circ} \mathrm{C}$ for $96 \mathrm{~h}$. A single colony of this culture was then transferred to fresh Wilbrink-N agar plates and again incubated at $28^{\circ} \mathrm{C}$ for $48 \mathrm{~h}$. From these cultures, a total of $30 \mu \mathrm{g}$ DNA with a concentration of at least $100 \mathrm{ng} / \mu \mathrm{l}$ and an OD260:280 rating between 1.8 and 2.0 was prepared using the Gentra Puregene Cell Kit (QIAGEN Benelux B.V., Venlo, The Netherlands), according to the manufacturer's instructions. Quantity and quality of the extracted DNA was checked using the NanoDrop 1000 spectrophotometer (Thermo Fisher Scientific, Wilmington, DE, USA).

\section{Sequencing, draft genome assembly and annotation}

Custom DNA library preparation and Illumina-sequencing was performed by Baseclear N.V., Leiden, The Netherlands. A first Paired-End (PE) DNA library with an a mean insert size of $375 \mathrm{bp}$ was sequenced with $50 \mathrm{bp}$ reads on an Illumina Genome Analyzer IIx (Illumina Inc., San-Diego, USA). A second, Mate-Paired (MP) DNA library with a mean insert size of $5100 \mathrm{bp}$ was sequenced with 75 bp reads on an Illumina Hiseq2000 (Illumina Inc.), but only the first 50 bp were used to avoid chimeric reads.

The received raw PE and MP read sets were quality trimmed in CLC Bio v4.0 (CLC bio, Aarhus, Denmark) using a Phred quality cut-off score of 20. An initial de novo assembly was performed in CLC Bio v4.0 using only the PE reads, and all contigs shorter than $200 \mathrm{bp}$ were discarded. This assembly was scaffolded in SSPACE Premium v2.0 [23] using MP reads and processed with the Gapcloser v1.12 tool of the SOAP genome assembly software [21]. Gapfiller and IMAGE were not used because the former was not yet freely available and the latter could not be operated as intended. Because Gapcloser did not recognize the Hiseq2000 file parsing of the MP dataset, only the PE data was used. Finally, the draft genome sequence was manually edited with the Editseq tool of DNAStar Lasergene core suite v10.0.1 (DNASTAR Inc., Madison, WI, USA). Remaining $\mathrm{N}$-nucleotides in the scaffolds, introduced during scaffolding and not replaced by gapcloser, were removed from the final sequence by breaking up the scaffolds back into contigs where they were encountered. The quality of the final draft genome sequence was compared to the initial PE-based de novo assembly through comparative read-mapping in CLC Bio v4.0 using both the trimmed read sets. The final draft genome sequence of Xf was putatively annotated with the RAST v4.0 online annotation pipeline [72] and NCBI's Prokaryotic Genomes Automatic Annotation Pipeline (PGAAP; http://www.ncbi.nlm.nih.gov/genomes/static/ Pipeline.html).

\section{Comparative genome analysis}

The presence of possible pathogenicity-related genes in the Xf draft genome was analysed by comparison with 25 other Xanthomonas genomes (Table 2). In a first explorative screening, the gene content of the Xf genome was compared with the chromosomes $X$. campestris pv. campestris (Xcc) ATCC 33913, X. euvesicatoria (Xcv) 85-10, X. oryzae pv. oryzae (Xoo) KACC 10331 and X. albilineans (Xalb) GPE PC73 in EDGAR [43]. Absence or presence of coding sequences in each genome, as reported by EDGAR, were independently confirmed by performing protein and nucleotide blast queries (as described below) in the target genomes before inclusion in this manuscript.

In a second phase, gene families of interest were examined in all 26 genomes. All genomes except three were screened using the protein and nucleotide blast tools of Genbank. Four genomes not present in Genbank were screened with the blast tool of the SEED Viewer v2.0 web-interface [73]: draft genomes of the present Xf strain LMG 25863, two X. arboricola strains LMG 19145 and LMG 19146 [39], and the X. arboricola pv. pruni strain LMG 25864 (M Maes, unpublished). Based on the EDGAR results, three protein families were studied in greater detail: the TonB-dependent transporters (TBDT), the cell-wall degrading enzymes (CWDE) and the Type III secretion system effectors (T3SE). 


\section{Phylogenetic relationship}

To determine the phylogenetic position of Xf within the Xanthomonas genus, we performed in silico multi-locus sequence analysis using partial sequences of the genes gyrB, rpoD, atpD, dnaK and $f y u A$, according to Parkinson et al. (2009) [40], Young et al. (2008) [41], and Ngoc et al. (2010) [42]. Sequences were retrieved from the Xf and the 25 other Xanthomonas genomes available in GenBank (Table 2). The sizes of the five partial sequences are 530 bp (gyrB), 747 bp (atpD), 940 bp (dnaK), 873 bp $(r p o D)$ and $698 \mathrm{bp}(f y u A)$, giving a total of $3788 \mathrm{bp}$ for the concatenated dataset. Sequences were concatenated and aligned using the CLUSTALW algorithm [74]. Sequence alignment, trimming, and phylogenetic analysis were performed in Mega5 [75]. The phylogenetic tree was generated using the Maximum Composite Likelihood method for calculating distances and the Neighbor Joining algorithm for clustering [76], bootstrap analysis was performed using 1000 bootstrap replicates.

\section{TonB-dependent receptors}

The TBDT repertoire of Xf was compared to that of the other 25 Xanthomonas genomes. The 72 TBDTs identified in Xcc ATCC 33913 [48] were used as primary references. Initially, the 26 genomes were screened for homologs of these primary references using protein blast queries. In case of a negative blast result, an additional nucleotide blast with the reference coding sequence was performed to exclude false negative results. TBDTs with low protein sequence similarity $(<70 \%)$ with the primary references were considered as new types and were added to the list of references. TBDTs in the more distantly related $X$. albilineans GPE PC73 and X. sacchari NCPPB 4393 occasionally showed ambiguous homology with more than one reference. This was resolved by reciprocal blast, after which the TBDT in question was assigned to the reference with the best blast hit score.

\section{Cell-wall degrading enzymes}

Reference sequences of different CWDE-families were retrieved from [26]. All 26 genomes were searched for homologs of these references in a similar fashion as applied for the TBDTs.

\section{Type III secretion effectors}

References of the presently known T3SEs in Xanthomonas were retrieved from the Xanthomonas Resource website [56] and all 26 genomes were screened for homologs. Because of their sometimes large diversity, the protein sequences of all encountered (putative) effectors were collected and compared in Bionumerics v6.6 (Applied Maths, Sint-Martens-Latem, Belgium). For each effector class, a protein-sequence based pairwise alignment similarity matrix was calculated using the standard
Bionumerics algorithm in its default settings. Candidate effectors of Xf were only considered as part of an effector class when it exhibited at least $60 \%$ pairwise similarity with at least one other entry in the matrix. Next, a binary table listing the presence or absence of at least one fully coded homolog of every known T3SE class in each of the 26 genomes was created. Truncated, frame-shifted or otherwise suspected incomplete or inactive coding sequences were interpreted as absent. When the full coding sequence could not be retrieved because of incomplete assembly, the effector was counted as present. Multiple homologs of an effector in a single genome were counted only once. This binary dataset was imported and analyzed in Bionumerics. A binary-data based distance matrix was calculated using the Hamming Distance parameter and a distance-based consensus network was calculated using the Neighbor Joining tree method in its default settings and bootstrap resampling with 1000 replications [77].

\section{Depositions}

The raw sequence data received from Baseclear N.V. (Leiden, The Netherlands) was deposited at the Short Read Archive (SRA) of Genbank under accession numbers SRR514114 (PE dataset) and SRR514113 (MP dataset). The current draft genome sequence was deposited at Genbank under accession number AJRZ00000000 after automatic annotation by the PGAAP online annotation pipeline.

\section{Additional files}

Additional file 1: Table S1. EDGAR output table. Raw output data of the EDGAR genome comparison, listing all CDSs shared among $X$. fragariae LMG 25863, X. albilineans GPE PC73, X. onyzae pv. oryzae KACC 10331, X. campestris pv. campestris ATCC 33913 and X. euvesicatoria 85-10.

Additional file 2: Table S2. TonB-dependent transporters. Occurrence of TonB-dependent transporters among the 26 studied Xanthomonas genomes. The 100 reference protein sequences are listed in the table rows, with the name of the genome they were retrieved from and their Genbank locus tags indicated in the first two columns. The remaining columns show the occurrence of homologs of each reference protein among the 26 genomes. "2": two homologs present; "1": one homolog present, " 0 ": no homolog found, " $\Psi T$ ": coding DNA sequence encountered, but protein believed inactive due to truncation;" $\Psi F^{\prime \prime}$ : coding DNA sequence encountered, but protein believed inactive due to frameshift, "Seq": coding DNA sequence truncated due to incomplete genome-assembly; functional protein assumed present during further processing of data. Underlined entries were not annotated in Genbank, and were retrieved using nucleotide blast queries.

Additional file 3: Table S3. Macerating enzymes. Occurrence of macerating enzymes among the 26 studied Xanthomonas genomes. The 46 reference protein sequences are listed in the table rows, with the name of the genome they were retrieved from and their Genbank locus tags indicated in the second and third columns. The remaining columns show the occurrence of homologs of each reference protein among the 26 genomes. "2": two homologs present; "1": one homolog present, "0": no homolog found, " $\Psi T^{\prime}$ : coding DNA sequence encountered, but protein believed inactive due to truncation;" $\Psi F^{\prime \prime}$ : coding DNA sequence 
encountered, but protein believed inactive due to frameshift, "Seq": coding DNA sequence truncated due to incomplete genome-assembly: functional protein assumed present during further processing of data. Underlined entries were not annotated in Genbank, and were retrieved using nucleotide blast queries.

Additional file 4: Table S4. Type III secretion effectors. Overview of the type III secretion effector repertoire in each of the 26 tested Xanthomonas genomes. "1": at least one homolog present, "O": no homolog found, " $\Psi T$ ": coding DNA sequence encountered, but protein believed inactive due to truncation;" $\Psi F^{\prime \prime}$ : coding DNA sequence encountered, but protein believed inactive due to frameshift," $\Psi I S^{\prime \prime}$ c coding DNA sequence encountered, but protein believed inactive due to inserted sequence, "Seq": coding DNA sequence truncated due to incomplete genome-assembly; functional protein assumed present during further processing of data. Underlined entries were not annotated in Genbank, and were retrieved using nucleotide blast queries.

\section{Competing interests}

The authors declare that they have no competing interests.

\section{Authors' contributions}

MM and PDV conceived the study and participated in its design and coordination. BC and JVD participated in the design of the study. JVD oversaw the genome assembly, automatic genome annotations and sequence depositions, and conducted the genome comparisons. SB conducted in the genome assembly, automatic genome annotations and sequence depositions. BC and JVD drafted the manuscript. All authors read and approved the final manuscript.

\section{Acknowledgements}

The authors would like to acknowledge Miss. Cinzia Van Malderghem at ILVO for her technical assistance during the genomic DNA preparation, and Prof. Dr. Tom Coenye of the Laboratory of Pharmaceutical Microbiology at Ghent University for his critical reading of the draft manuscript. This work was made possible through the financial support of the Institute for the Promotion of Innovation by Science and Technology in Flanders (IWT) under project nr. 070597.

\section{Author details}

'Institute for Agricultural and Fisheries Research (ILVO), Plant Sciences Unit Crop Protection, Merelbeke, Belgium. ${ }^{2}$ Laboratory of Microbiology, Ghent University, K. L. Ledeganckstraat 35, Ghent 9000, Belgium.

Received: 28 November 2012 Accepted: 20 November 2013 Published: 25 November 2013

\section{References}

1. Kennedy BW, King TH: Angular leaf spot of strawberry caused by Xanthomonas fragariae sp. nov. Phytopathology 1962, 52:873-875.

2. Maas JL: Angular leaf spot. In Compendium of Strawberry Diseases. 2nd edition. Edited by Maas JL. St. Paul, MN-USA: American Phytopathological Society; 1998:16-17.

3. European Commission: EC Council Directive 2000/29/EC of 8 May 2000 on Protective measures against the introduction into the Community of organisms harmful to plants or plant products and against their spread within the Community. In OJEU. Luxembourg: Publications Office of the European Union, Luxembourg; 2000:1-112.

4. Dye DW, Lelliott RA, Buchanan RE, Gibbons NE: Genus II. Xanthomonas Dowson 1939, 187. In Bergey's Manual of Determinative Bacteriology. 8th edition. Edited by Bergey DH, Buchanan RE, Gibbons NE. Baltimore, USA: Williams \& Wilkins Co; 1974:243-249.

5. Van den Mooter M, Swings J: Numerical analysis of 295 phenotypic features of 266 Xanthomonas strains and related strains and an improved taxonomy of the genus. Int J Syst Bacteriol 1990, 40:348-369.

6. Vauterin L, Hoste B, Kersters K, Swings J: Reclassification of Xanthomonas. Int J Syst Bacteriol 1995, 45:472-489.

7. Vauterin L, Rademaker J, Swings J: Synopsis on the taxonomy of the genus Xanthomonas. Phytopathology 2000, 90:677-682.

8. Pooler MR, Ritchie DF, Hartung JS: Genetic relationships among strains of Xanthomonas fragariae based on random amplified polymorphic DNA $\mathrm{PCR}$, repetitive extragenic palindromic $\mathrm{PCR}$, and enterobacterial repetitive intergenic consensus PCR data and generation of multiplexed PCR primers useful for the identification of this phytopathogen. Appl Environ Microbiol 1996, 62:3121-3127.

9. Roberts PD, Hodge NC, Bouzar H, Jones JB, Stall RE, Berger RD, Chase AR: Relatedness of strains of Xanthomonas fragariae by restriction fragment length polymorphism, DNA-DNA reassociation, and fatty acid analyses. Appl Environ Microbiol 1998, 64:3961-3965.

10. Stöger A, Barionovi D, Calzolari A, Gozzi R, Ruppitsch W, Scortichini M: Genetic variability of Xanthomonas fragariae strains obtained from field outbreaks and culture collections as revealed by repetitive-sequence PCR and AFLP. J Plant Pathol 2008, 90:469-473.

11. Kennedy BW: Infection of Potentilla by Xanthomonas fragariae. Plant Dis Rep 1965, 49:491-492.

12. Roberts PD, Berger RD, Jones JB, Chandler CK, Stall RE: Disease progress, yield loss, and control of Xanthomonas fragariae on strawberry plants. Plant Dis 1997, 81:917-921.

13. Mahuku GS, Goodwin PH: Presence of Xanthomonas fragariae in symptomless strawberry crowns in Ontario detected using a nested polymerase chain reaction (PCR). Can J Plant Pathol 1997, 19:366-370.

14. Moltmann E, Zimmermann C: Detection of Xanthomonas fragariae in symptomless strawberry plants by nested PCR. EPPO Bull 2005, 35:53-54

15. Milholland RD, Ritchie DF, Daykin ME, Gutierrez WA: Multiplication and translocation of Xanthomonas fragariae in strawberry. Adv Strawb Res 1996, 15:13-17.

16. Hildebrand PD, Braun PG, Renderos WE, Jamieson AR, McRae KB, Binns MR: A quantitative method for inoculating strawberry leaves with Xanthomonas fragariae, factors affecting infection, and cultivar reactions. Can J Plant Pathol 2005, 27:16-24.

17. MacLean D, Jones JDG, Studholme DJ: Application of 'next-generation' sequencing technologies to microbial genetics. Nat Rev Microbiol 2009, 7:287-296.

18. Büttner D, Bonas U: Regulation and secretion of Xanthomonas virulence factors. FEMS Microbiol Rev 2009, 34:107-133.

19. Ryan RP, Vorhölter FJ, Potnis N, Jones JB, Van Sluys MA, Bogdanove AJ, Dow JM: Pathogenomics of Xanthomonas: understanding bacterium-plant interactions. Nat Rev Microbiol 2011, 9:344-355.

20. Treangen TJ, Salzberg SL: Repetitive DNA and next-generation sequencing: computational challenges and solutions. Nat Rev Genet 2011, 13:36-46.

21. Li R, Fan W, Tian G, Zhu H, He L, Cai J, Huang Q, Cai Q, Li B, Bai Y: The sequence and de novo assembly of the giant panda genome. Nature 2009, 463:311-317.

22. Tsai I, Otto T, Berriman M: Improving draft assemblies by iterative mapping and assembly of short reads to eliminate gaps. Genome Biol 2010, 11:R41.

23. Boetzer M, Henkel CV, Jansen HJ, Butler D, Pirovano W: Scaffolding pre-assembled contigs using SSPACE. Bioinformatics 2011, 27:578-579.

24. Potnis N, Krasileva K, Chow V, Almeida NF, Patil PB, Ryan RP, Sharlach M, Behlau F, Dow JM, Momol MT: Comparative genomics reveals diversity among xanthomonads infecting tomato and pepper. BMC Genomics 2011, 12:146.

25. Pieretti I, Royer M, Barbe V, Carrere S, Koebnik R, Cociancich S, Couloux A, Darrasse A, Gouzy J, Jacques MA: The complete genome sequence of Xanthomonas albilineans provides new insights into the reductive genome evolution of the xylem-limited Xanthomonadaceae. BMC Genomics 2009, 10:616.

26. Da Silva $A C R$, Ferro JA, Reinach $F C$, Farah CS, Furlan LR, Quaggio RB, Monteiro-Vitorello CB, Van Sluys MA, Almeida NF, Alves LMC, Do Amaral AM, Bertolini MC, Camargo LEA, Camarotte G, Cannavan F, Cardozo J, Chambergo F, Ciapina LP, Cicarelli RMB, Coutinho LL, Cursino-Santos JR, El-Dorry H, Faria JB, Ferreira AJS, Ferreira RCC, Ferro MIT, Formighieri EF, Franco MC, Greggio CC, Gruber A, et al: Comparison of the genomes of two Xanthomonas pathogens with differing host specificities. Nature 2002, 417:459-463.

27. Jalan N, Aritua V, Kumar D, Yu F, Jones JB, Graham JH, Setubal JC, Wang N: Comparative genomic analysis of Xanthomonas axonopodis pv. citrumelo $\mathrm{F} 1$, which causes citrus bacterial spot disease, and related strains provides insights into virulence and host specificity. J Bacterio/ 2011 193:6342-6357.

28. Sharma V, Midha S, Ranjan M, Pinnaka AK, Patil PB: Genome sequence of Xanthomonas axonopodis pv. punicae strain LMG 859. J Bacteriol 2012, 194:2395.

29. Studholme DJ, Kemen E, MacLean D, Schornack S, Aritua V, Thwaites R, Grant M, Smith J, Jones JD: Genome-wide sequencing data reveals 
virulence factors implicated in banana Xanthomonas wilt. FEMS Microbiol Lett 2010, 310:182-192.

30. Qian W, Jia Y, Ren SX, He YQ, Feng JX, Lu LF, Sun Q, Ying G, Tang DJ, Tang $\mathrm{H}$ : Comparative and functional genomic analyses of the pathogenicity of phytopathogen Xanthomonas campestris pv. campestris. Genome Res 2005, 15:757-767.

31. Vorhölter FJ, Schneiker S, Goesmann A, Krause L, Bekel T, Kaiser O, Linke B, Patschkowski T, Rückert C, Schmid J: The genome of Xanthomonas campestris pv. campestris B100 and its use for the reconstruction of metabolic pathways involved in xanthan biosynthesis. J Biotechnol 2008, 134:33-45.

32. Bogdanove AJ, Koebnik R, Lu H, Furutani A, Angiuoli SV, Patil PB, Van Sluys MA, Ryan RP, Meyer DF, Han SW: Two new complete genome sequences offer insight into host and tissue specificity of plant pathogenic Xanthomonas spp. J Bacteriol 2011, 193:5450-5464.

33. Thieme F, Koebnik R, Bekel T, Berger C, Boch J, Büttner D, Caldana C, Gaigalat L, Goesmann A, Kay S: Insights into genome plasticity and pathogenicity of the plant pathogenic bacterium Xanthomonas campestris pv. vesicatoria revealed by the complete genome sequence. J Bacteriol 2005, 187:7254-7266

34. Midha S, Ranjan M, Sharma V, Pinnaka AK, Patil PB: Genome sequence of Xanthomonas citri pv. mangiferaeindicae strain LMG 941. J Bacterio/ 2012 194:3031.

35. Moreira LM, Almeida NF, Potnis N, Digiampietri LA, Adi SS, Bortolossi JC, da Silva AC, Da Silva AM, De Moraes FE, De Oliveira JC: Novel insights into the genomic basis of citrus canker based on the genome sequences of two strains of Xanthomonas fuscans subsp. aurantifolii. BMC Genomics 2010, 11:238.

36. Lee BM, Park YJ, Park DS, Kang HW, Kim JG, Song ES, Park IC, Yoon UH, Hahn JH, Koo BS: The genome sequence of Xanthomonas oryzae pathovar oryzae KACC10331, the bacterial blight pathogen of rice. Nucleic Acids Res 2005, 33:577-586.

37. Ochiai H, Inoue Y, Takeya M, Sasaki A, Kaku H: Genome sequence of Xanthomonas oryzae pv. oryzae suggests contribution of large numbers of effector genes and insertion sequences to its race diversity. JARQ 2005, 39:275.

38. Salzberg SL, Sommer DD, Schatz MC, Phillippy AM, Rabinowicz PD, Tsuge S, Furutani A, Ochiai H, Delcher AL, Kelley D: Genome sequence and rapid evolution of the rice pathogen Xanthomonas oryzae pv. oryzae PXO99A BMC Genomics 2008, 9:204.

39. Vandroemme J, Cottyn B, Pothier JF, Pflüger V, Duffy B, Maes M: Xanthomonas arboricola pv. fragariae: what's in a name? Plant Pathol: doi:10.1111/ppa.12028.

40. Parkinson N, Cowie C, Heeney J, Stead D: Phylogenetic structure of Xanthomonas determined by comparison of gyrB sequences. Int J Syst Evol Micr 2009, 59:264-274.

41. Young JM, Park DC, Shearman HM, Fargier E: A multilocus sequence analysis of the genus Xanthomonas. Syst Appl Microbiol 2008, 31:366-377.

42. Ngoc LBT, Verniere C, Jouen E, Ah-You N, Lefeuvre P, Chiroleu F, Gagnevin L, Pruvost O: Amplified fragment length polymorphism and multilocus sequence analysis-based genotypic relatedness among pathogenic variants of Xanthomonas citri pv. citri and Xanthomonas campestris pv. bilvae. Int J Syst Evol Micr 2010, 60:515-525.

43. Blom J, Albaum SP, Doppmeier D, Pühler A, Vorhölter FJ, Zakrzewski M, Goesmann A: EDGAR: a software framework for the comparative analysis of prokaryotic genomes. BMC Bioinforma 2009, 10:154.

44. Szczesny R, Jordan M, Schramm C, Schulz S, Cogez V, Bonas U, Büttner D: Functional characterization of the Xcs and Xps type II secretion systems from the plant pathogenic bacterium Xanthomonas campestris pv. vesicatoria. New Phytol 2010, 187:983-1002.

45. Lu H, Patil P, Van Sluys MA, White FF, Ryan RP, Dow JM, Rabinowicz P, Salzberg SL, Leach JE, Sonti R: Acquisition and evolution of plant pathogenesis-associated gene clusters and candidate determinants of tissue-specificity in Xanthomonas. PLoS One 2008, 3:e3828.

46. Dunn MF, Ramírez-Trujillo JA, Hernández-Lucas I: Major roles of isocitrate lyase and malate synthase in bacterial and fungal pathogenesis. Microbiology 2009, 155:3166-3175.

47. Schatschneider S, Vorhölter FJ, Rückert C, Becker A, Eisenreich W, Pühler A, Niehaus K: Genome-enabled determination of amino acid biosynthesis in Xanthomonas campestris pv. campestris and identification of biosynthetic pathways for alanine, glycine, and isoleucine by 13 C-isotopologue profiling. Mol Genet Genomics 2011, 286:247-259.
48. Blanvillain S, Meyer D, Boulanger A, Lautier M, Guynet C, Denancé N, Vasse J, Lauber E, Arlat M: Plant carbohydrate scavenging through TonB-dependent receptors: a feature shared by phytopathogenic and aquatic bacteria. PLoS One 2007, 2:e224.

49. Dejean $G$, Blanvillain-Baufume $S$, Boulanger A, Darrasse A, de Bernonville TD, Girard AL, Carrere S, Jamet S, Zischek C, Lautier M, Sole M, Buttner D, Jacques MA, Lauber E, Arlat M: The xylan utilization system of the plant pathogen Xanthomonas campestris pv campestris controls epiphytic life and reveals common features with oligotrophic bacteria and animal gut symbionts. New Phytol 2013, 198:899-915.

50. Epstein $\mathrm{W}$ : The roles and regulation of potassium in bacteria. Prog Nucleic Acid Re 2003, 75:293-320.

51. MacLean AM, MacPherson G, Aneja P, Finan TM: Characterization of the b-ketoadipate pathway in Sinorhizobium meliloti. Appl Environ Microbiol 2006, 72:5403-5413.

52. Bugg TDH, Ahmad M, Hardiman EM, Singh $\mathrm{R}$ : The emerging role for bacteria in lignin degradation and bio-product formation. Curr Opin Biotech 2011, 22:394-400.

53. Cantu D, Vicente AR, Labavitch JM, Bennett AB, Powell ALT: Strangers in the matrix: plant cell walls and pathogen susceptibility. Trends Plant Sci 2008, 13:610-617.

54. Wang SY, Lin HS: Antioxidant activity in fruits and leaves of blackberry, raspberry, and strawberry varies with cultivar and developmental stage. J Agr Food Chem 2000, 48:140-146.

55. Morrissey JP: Biological activity of defence-related plant secondary metabolites. In Plant-Derived Natural Products: Synthesis, Function, and Application. Edited by Osbourn AE, Lanzotti V. New York, NY-USA: Springer; 2009:283-299.

56. White FF, Potnis N, Jones JB, Koebnik R: The type III effectors of Xanthomonas. Mol Plant Pathol 2009, 10:749-766.

57. Boch J, Bonas U: Xanthomonas AvrBs3 family-type III effectors: discovery and function. Annu Rev Phytopathol 2010, 48:419-436.

58. Kim JGUN, Taylor KW, Mudgett MB: Comparative analysis of the XopD type III secretion (T3S) effector family in plant pathogenic bacteria. Mol Plant Pathol 2011, 12:715-730.

59. Koebnik R, Krüger A, Thieme F, Urban A, Bonas U: Specific binding of the Xanthomonas campestris pv. vesicatoria AraC-type transcriptional activator HrpX to plant-inducible promoter boxes. J Bacteriol 2006, 188:7652-7660.

60. Boyer F, Fichant G, Berthod J, Vandenbrouck Y, Attree I: Dissecting the bacterial type $\mathrm{VI}$ secretion system by a genome wide in silico analysis: what can be learned from available microbial genomic resources? BMC Genomics 2009, 10:104.

61. Jani AJ, Cotter PA: Type VI secretion: not just for pathogenesis anymore. Cell Host Microbe 2010, 8:2-6.

62. Schwarz S, Hood RD, Mougous JD: What is type VI secretion doing in all those bugs? Trends Microbiol 2010, 18:531-537.

63. Zhang W, Xu S, Li J, Shen X, Wang Y, Yuan Z: Modulation of a thermoregulated type $\mathrm{VI}$ secretion system by $\mathrm{AHL}$-dependent quorum sensing in Yersinia pseudotuberculosis. Arch Microbiol 2011, 193:351-363.

64. Darrow GM: The strawberry. History, breeding and physiology. New York, NY-USA: Holt, Rinehart \& Winston; 1966.

65. Purugganan MD, Fuller DQ: The nature of selection during plant domestication. Nature 2009, 457:843-848.

66. Van Melderen L: Toxin-antitoxin systems: why so many, what for? Curr Opin Microbiol 2010, 13:781-785.

67. Linhartová I, Bumba L, Mašín J, Basler M, Osicka R, Kamanová J, Procházková K, Adkins I, Hejnová-Holubová J, Sadílková L, Morová J, Šebo P: RTX proteins: a highly diverse family secreted by a common mechanism. FEMS Microbio/ Rev 2010, 34:1076-1112.

68. Marraffini LA, Sontheimer EJ: CRISPR interference: RNA-directed adaptive immunity in bacteria and archaea. Nat Rev Genet 2010, 11:181-190.

69. Georgiades K, Raoult D: Genomes of the most dangerous epidemic bacteria have a virulence repertoire characterized by fewer genes but more toxin-antitoxin modules. PLOS One 2011, 6:e17962.

70. Vandroemme J, Baeyen S, Van Vaerenbergh J, De Vos P, Maes M: Sensitive real-time PCR detection of Xanthomonas fragariae in strawberry plants. Plant Pathol 2008, 57:438-444.

71. Koike $H$ : The aluminium-cap method for testingsugarcane varieties against leaf scald disease. Phytopathology 1965, 55:317-319.

72. Aziz R, Bartels D, Best A, DeJongh M, Disz T, Edwards R, Formsma K, Gerdes S, Glass E, Kubal M: The RAST Server: rapid annotations using subsystems technology. BMC Genomics 2008, 9:75. 
73. Overbeek R, Begley T, Butler RM, Choudhuri JV, Chuang HY, Cohoon M, de Crécy-Lagard V, Diaz N, Disz T, Edwards R: The subsystems approach to genome annotation and its use in the project to annotate 1000 genomes. Nucleic Acids Res 2005, 33:5691-5702.

74. Thompson JD, Higgins DG, Gibson TJ: Clustal-W - improving the sensitivity of progressive multiple sequence alignment through sequence weighting position-specific gap penalties and weight matrix choice. Nucleic Acids Res 1994, 22:4673-4680

75. Tamura K, Peterson D, Peterson N, Stecher G, Nei M, Kumar S: MEGA5: molecular evolutionary genetics analysis using maximum likelihood, evolutionary distance, and maximum parsimony methods. Mol Biol Evol 2011, 28:2731-2739.

76. Saitou N, Nei M: The neighbor-joining method - a new method for reconstructing phylogenetic trees. Mol Biol Evol 1987, 4:406-425.

77. Pouseele $H$, Vauterin $P$, Vauterin $L:$ A resampling strategy for reliable network construction. Mol Phylogenet Evol 2011, 60:273-286.

doi:10.1186/1471-2164-14-829

Cite this article as: Vandroemme et al:: Draft genome sequence of Xanthomonas fragariae reveals reductive evolution and distinct virulence-related gene content. BMC Genomics 2013 14:829.

\section{Submit your next manuscript to BioMed Central and take full advantage of:}

- Convenient online submission

- Thorough peer review

- No space constraints or color figure charges

- Immediate publication on acceptance

- Inclusion in PubMed, CAS, Scopus and Google Scholar

- Research which is freely available for redistribution 